\title{
Aquatic metabolism as an indicator of the ecological effects of hydrologic pulsing in flow-through wetlands
}

\author{
Cassandra L. Tuttle and William J. Mitsch \\ Wilma H. Schiermeier Olentangy River Wetland Research Park, Environmental Science Graduate Program, \\ The Ohio State University
}

\begin{abstract}
Water column metabolism is a major component in the functioning of wetland ecosystems and can be used as an indicator of ecosystem health. The effect of hydrologic pulsing on water column metabolism was studied with two year's field data and a validated model for two 1-ha created riparian wetlands at the Olentangy River Wetland Research Park at the Ohio State University, in Columbus, $\mathrm{OH}$, USA. Aquatic gross primary productivity (GPP) was measured during hydrologic pulses the first week of April, May and June of 2004 and compared to GPP during steady flow-conditions in April, May and June 2005. Pulses reduced diurnal variation of water temperature, $\mathrm{pH}$ and dissolved oxygen (DO), and negatively affected GPPrates. Mean GPP measured during hydrologic flood pulses was $5.13 \pm 0.3 \mathrm{kcal}$ $\mathrm{m}^{-2} \mathrm{~d}^{-1}$, which was significantly lower than that measured for comparable months with steady-flow hydrology (11.4 $\left.\pm 0.7 \mathrm{kcal} \mathrm{m}^{-2} \mathrm{~d}^{-1}\right)$. Solar corrected productivity values of $0.08 \pm 0.01 \%$ of solar energy during pulses and $0.2 \pm 0.02 \%$ for steady-flow conditions were also significantly different. Different hyperbolic curves of optimum productivity with water temperature were seen for pulsing and steady-flow conditions. Asimulation model with hydrology, metabolism, and DO sub models was was calibrated with 2005 steadyflow year data and validated with 2004 pulse year data. Results from both the field study and model simulations suggest that there was a threshold hydraulic inflow rate between 30 and $50 \mathrm{~cm} \mathrm{~d}^{-1}$ where aquatic metabolism became negatively affected due to direct and indirect effects of the hydrologic pulse.
\end{abstract}

\section{Introduction}

Aquatic metabolism - the productivity and respiration of the shallow water column - provides a useful composite indicator of ecosystem function in wetlands. Hydrologic pulsing can either positively or negatively affect this metabolism. Increased flow rates stimulate aquatic metabolism by accelerating nutrient uptake, photosynthesis, respiration and reproduction rates of aquatic producers (Stevenson, 1996). Positive effects of current on aquatic production generally increase with increased nutrient concentrations. Where river inflow is a significant source of nutrients, higher flow rates can support higher aquatic productivity as demonstrated by Cronk and Mitsch (1994a) in created riparian wetlands. Increased current also acts to ameliorate the negative effects of biomass density in established algal mats by transporting nutrients through the mat and washing away senescent cells (Peterson, 1996; Stevenson, 1996). Aquatic production can be stimulated by periodic pulses that suppress predators, flush toxins and waste materials from the system, and create new substrate space for colonization (Mosisch and Bunn, 1997). In addition, seasonal flood pulses may indirectly contribute to long-term positive effects for the aquatic community by reducing macrophyte abundance and releasing nutrients previously stored in vegetation biomass (Godsborough and Robinson, 1996).

Increased water velocity as a result of hydrologic pulsing negatively affects aquatic productivity by increasing drag forces on cells creating an environmental stress, and causing export of biomass from the system. In extreme instances, abrupt increases in current velocity due to high amplitude flood pulses can result in a complete denudation of the producer community (Peterson, 1996: Stevenson, 1996; Mosisch and Bunn, 1997). However, when algal mats and senescent vegetation are removed, productivity may be stimulated following the disturbance due to increased light availability and water temperatures (Peterson, 1996). Maximum rates of aquatic primary productivity likely occur at intermediate current velocities, where benefits of higher flow stimulate growth, but do not exert enough drag to be considered an environmental stress (Stevenson, 1996).

Simulation models have frequently been employed to describe the connectivity among abiotic and biotic factors in wetlands. These models provide useful tools for evaluating the importance of ecological indicators in ecosystem function. For wetland ecosystems, dynamic models have been developed in order to simulate and predict hydrology (Zhang and Mitsch, 2005), aquatic community development and trophic structure (Metzker and Mitsch, 1997; Spieles and Mitsch, 2003), nutrient removal and transformation in relation to hydrology and productivity (Mitsch and Reeder, 1991; Christensen et al., 1994; Wang and Mitsch, 2000; Spieles and Mitsch, 2000), desirable wetland characteristics and size related to nutrient removal from non-point source pollution (Mitsch and Wang, 2000), and response of wetland ecosystems to nutrient enrichment (Buzzelli et al., 2000). For example, Mitsch and Reeder (1991) developed a model to study nutrient retention in a coastal wetland on Lake Erie and to investigate the roles of planktonic and macrophyte productivity, sedimentation, resuspension and hydrology. 
Specific simulations of storm events with increased inflow and phosphorus loading, but high plankton export as well, demonstrated that pulsed hydrologic conditions increased sedimentation and phosphorus retention rates, but reduced planktonic productivity and resulted in lower percent removal of phosphorus than for normal flow conditions.

The goal of this study was to examine the influence of seasonal hydrologic pulsing on aquatic metabolism in two created flow-through riparian wetlands. The following objectives were established to determine this relationship:

1) investigate the impact of seasonal hydrologic pulsing on spatially explicit patterns of dissolved oxygen and aquatic productivity and respiration; and

2) develop, calibrate and validate an ecosystem model that describes the observed effect of hydrologic pulsing on dissolved oxygen aquatic metabolism dynamics.

\section{Methods}

\section{Site description}

This study was carried out at the Wilma H. Schiermeier Olentangy River Wetland Research Park, a 12-ha wetland research facility located on the campus of The Ohio State University in Columbus, Ohio, USA. The two 1-ha experimental wetlands used for this research (Figure 1) were created in 1994 and have been continuously pumped with river water from the bordering Olentangy River at an average rate of 20-30 $\mathrm{m} \mathrm{yr}^{-1}$ to each (Mitsch et al., 1998, 2005a,b). In May 1994, Wetland 1 (W1) was planted with 13 species characteristic of freshwater marshes in the midwestern USA, while Wetland 2 (W2) remained unplanted.

Each wetland was designed to have three distinct "deepwater" areas, hereby referred to as the inflow, middle, and outflow basins. Over the 10 years since the wetlands were created water depth in these deepwater basins was

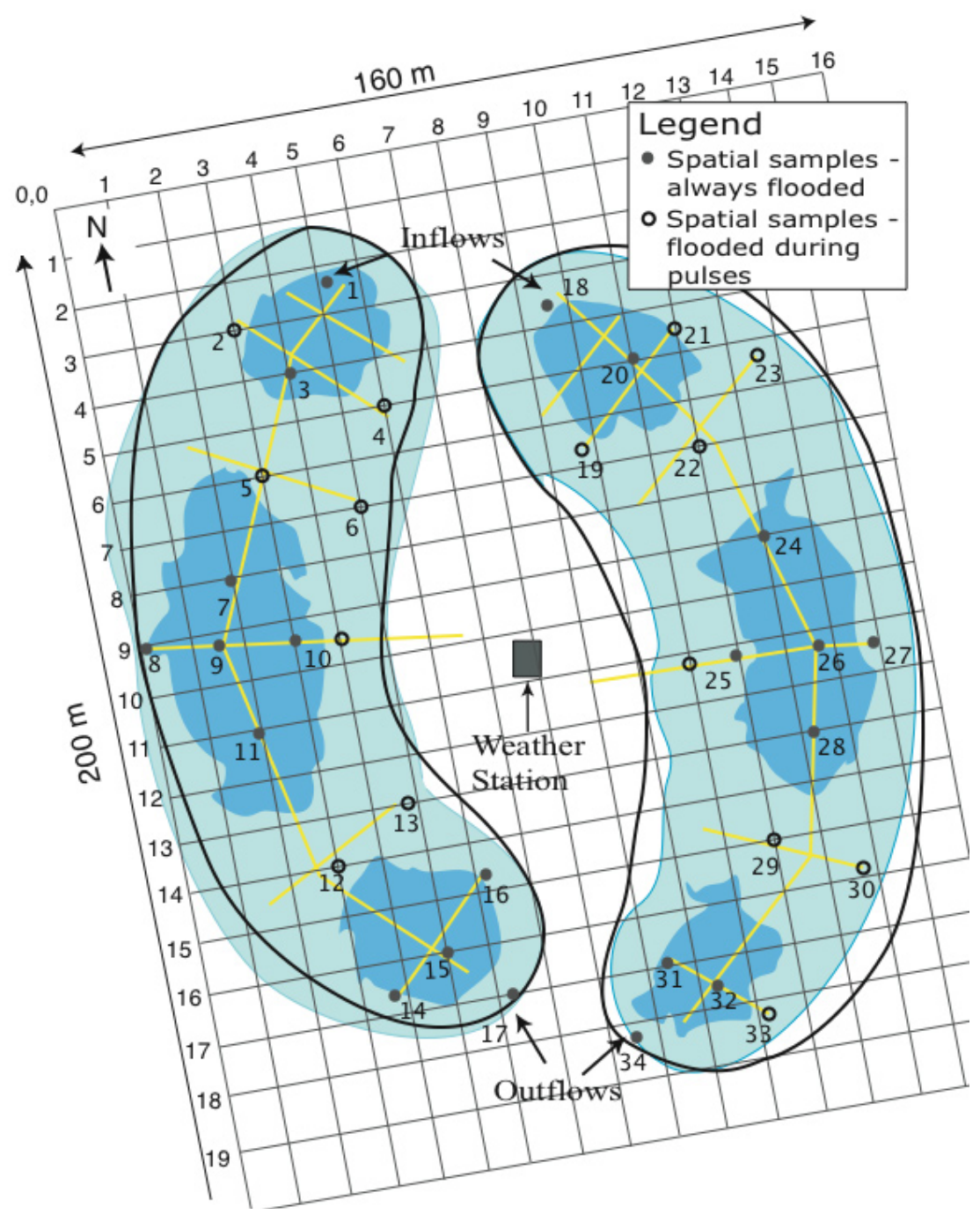

Figure 1. Sample sites established in the experimental wetlands at the Olentangy River Wetland Research Park in Columbus USA for spatial sampling of water quality parameters, chlorophyll-a and aquatic vegetation biomass. 


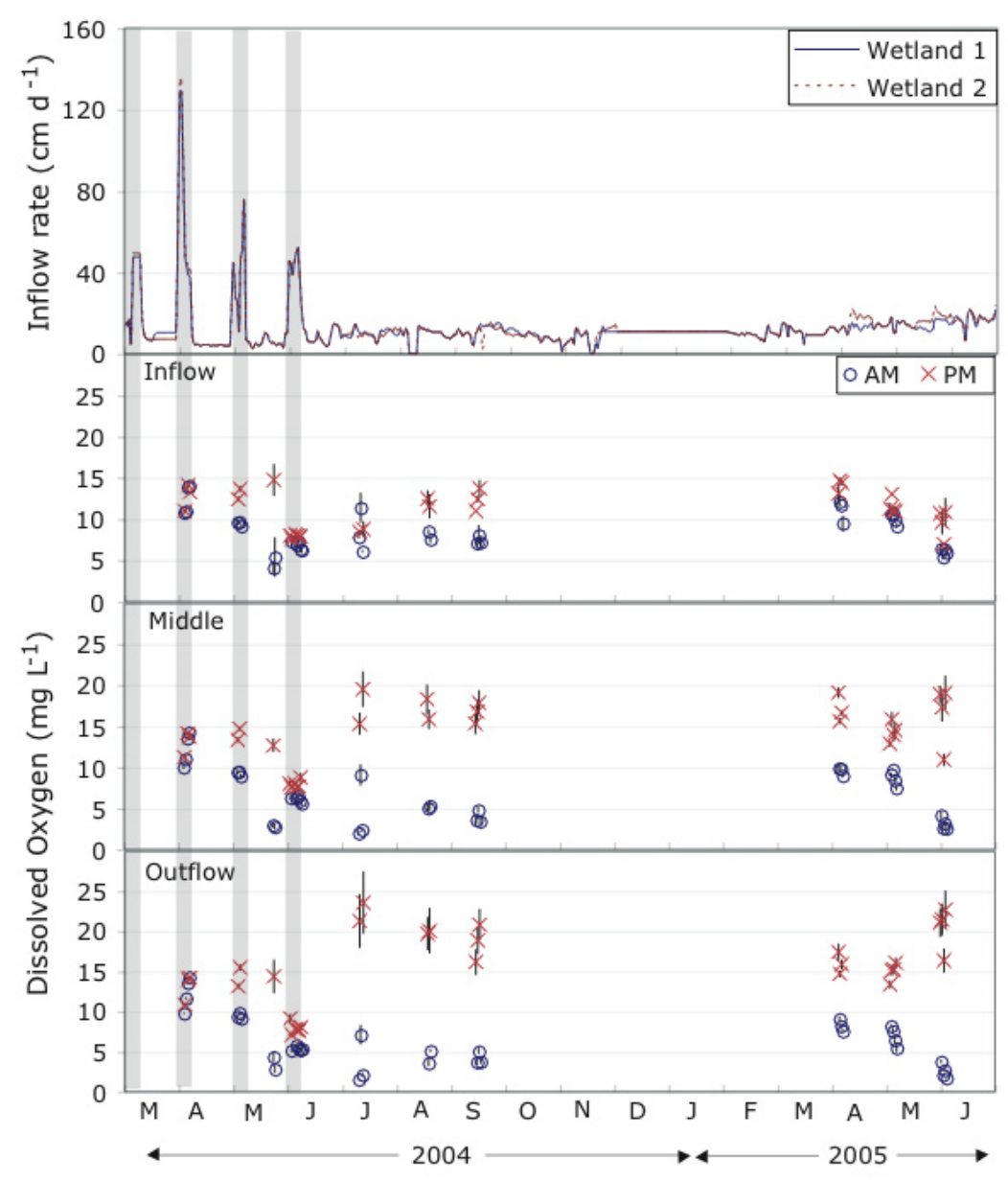

Figure 2. Hydraulic loading rate and dawn-dusk dissolved oxygen measured in the inflow, middle, and outflow basins of the experimental wetlands throughout the study period. Hydrologic pulse times are indicated by grey columns. Error bars indicate standard error.

generally $60-80 \mathrm{~cm}$, while depth in remaining shallow marsh areas ranged between $20-40 \mathrm{~cm}$. Previous studies in these experimental wetlands have investigated their water quality role and succession (Mitsch et al., 1998, 2005a,b; Nairn and Mitsch, 2000), sedimentation (Harter and Mitsch, 2003; Nahlik and Mitsch, 2006), algal spatial patterns (Wu and Mitsch, 1998), nitrogen and carbon dynamics (Spieles and Mitsch, 2000; Altor and Mitsch, 2006; Hernandez and Mitsch, 2006) and soil development (Anderson et al., 2005, Anderson and Mitsch, 2006).

Commonemergentmacrophytespeciescurrentlyidentified in the wetlands include Schoenoplectus tabernaemontani, Scirpus fluviatilis, Sparganium eurycarpum, Spartina pectinata, Typha spp., Polygonum spp., and Leersia oryzoides. Differences between the planted and unplanted wetlands remain ten years after planting (Mitsch et al., 2005b). Submerged macrophytes observed at the site during the study period (2004-05) include pondweed (Potamogeton Pusillus L.), longleaf pondweed (Potamogeton nodosus Poir.), curly pondweed (Potamogeton crispus L.), coons tail (Ceratophyllum demersum L.), water-nymph (Najas spp.), water lily (Nymphaea L.), and duckweed (Lemna
L.). Previous studies at the site have identified more than 100 genera of algae, including 14 genera of cyanobacteria. Dominant macroalgal populations generally consist of Hydrodictyon, Cladophora, Rhizoclonium and Spirogyra (Kantz and Deal, 1999), and additional filamentous genera include Ulothrix, Microspora, Stigeoclonium, Zygnema, Bulbochaete, Mougeotia and Sirogonium (Deal and Kantz, 1997).

\section{Pulsing experiment}

This study was one part of an ecosystem-scale pulsing experiment carried out in the experimental wetlands starting in 2003. Seasonal flood pulses were simulated in 2004 by pumping river water at a high rate during the first week of each month from January through June, and wetlands were maintained with steady flow from July through December (Mitsch et al., 2005b) (Figure 2). In the control year 2005, the wetlands were maintained with steady-flow conditions by pumping river water at a steady rate throughout the whole year, while maintaining approximately the same total water volume flow-through as in 2004 . The average inflow rates during sample periods was $45 \pm 5.8 \mathrm{~cm} \mathrm{~d}^{-1}$ during 
pulses, and $15 \pm 0.6 \mathrm{~cm} \mathrm{~d}^{-1}$ for steady-flow conditions. Pulse magnitudes between months varied and the average pumped inflow rates to the wetlands for sample periods during pulses were $66 \pm 10.6 \mathrm{~cm} \mathrm{~d}^{-1}, 28 \pm 4.7 \mathrm{~cm} \mathrm{~d}^{-1}$, and $42 \pm 2.1 \mathrm{~cm} \mathrm{~d}^{-1}$ for April, May and June respectively. The low average pulse magnitude in May was the result of a temporary pump shutdown that occurred on May 4, stopping the inflow for part of the day.

\section{Aquatic metabolism}

Thirty-two sample locations, sixteen in each experimental wetland, were chosen to represent deep-water and shallow areas (Figure 1). Dissolved oxygen (DO) concentration $\left(\mathrm{mg} \mathrm{L}^{-1}\right)$, and water temperature $\left({ }^{\circ} \mathrm{C}\right)$ were measured at each site using a YSI 650 display unit and a YSI 600 series data sonde (YSI Inc., Yellow Springs, OH). The data sonde was calibrated on a regular basis and checked for accuracy before each sampling period. Solar radiation was measured at a site between the two wetlands from October 2004 through June of 2005 with a LI-200 SA pyranometer sensor measuring short wave radiation $\left(400-1100 \mathrm{~nm} \mathrm{~W} \mathrm{~m}^{-2}\right)$. Values prior to October 2004 were estimated from data recorded at an Ohio Agricultural Research and Development Center (OARDC) weather station located $40 \mathrm{~km}$ away $\left(40^{\circ} 21^{\prime}\right.$ $\mathrm{N}, 83^{\circ} 04^{\prime} \mathrm{W}$ ) in Delaware, Ohio that was later calibrated to the onsite pyranometer.

Spatial measurements of DO were taken for each site at dawn and dusk during the first week of April, May, and June, during flood pulses in 2004, and steady-flow conditions in 2005. Supplemental sampling was also done during drawdown conditions the week of May 23, 2004 prior to the June pulse, and once per month during steady-flow conditions July through September 2004. Data collected during supplemental sampling periods were used to make general observations and to aid with model development and calibration, but were not included for comparison of pulsed versus steady-flow conditions. Water column gross primary production (GPP) was calculated using the dawn-dusk-dawn method of Odum and Hoskin (1958). If calculated GPP was negative it was assumed to be zero. GPP in terms of $\mathrm{g}-\mathrm{O}_{2} \mathrm{~m}^{-2}$ $\mathrm{d}^{-1}$ was converted to energy by multiplying by 3.7 (Mitsch and Gosselink, 2000) and normalized by converting it to percent solar efficiency. Dawn-dusk data were compared between Wetland 1 and Wetland 2. When comparing years, the two experimental wetlands were treated as replicates and data were combined. All statistical analysis was done using univariate analysis of variance (ANOVA) at a 0.05 confidence level, with SPSS 11 (SPSS Inc. Chicago, IL) for MAC OS X.

\section{Modeling}

The simulation model developed for this project (Figure 3a) consists of three unit models representing different aspects of ecosystem function. Sub-models for hydrology, aquatic metabolism and DO were developed for conditions specific to each of the three deepwater basins in the two experimental wetlands. The model was developed with STELLA $^{\text {TM }} 8.0$ software (Isee Inc., Lebanon, $\mathrm{NH}$ ) on an Apple $^{\mathrm{TM}}$ Powerbook G4 laptop computer using nonlinear, ordinary differential equations. Integration was done using the fourth-order Runge-Kutta integration method with a time step 0.1 days. Production by different algal assemblages and submerged macrophytes were aggregated into one state variable to describe all primary productivity in the system. Each of the three deepwater basins in the two experimental basins was treated as a separate unit and identical submodels describing hydrology, aquatic metabolism, and DO were replicated for each and connected by hydrologic flowthrough (Figure $3 b$ ). Model structure for each wetland was identical except minor differences of input data for hydrology and water temperature. Equations and parameters in the three submodels are provided in Appendix A, and are described in more detail by Tuttle (2005). The model was calibrated with a stepwise technique used previously in wetland models (Mitsch and Reeder, 1991; Christensen et al., 1994; Wang and Mitsch, 2000), using data collected in the experimental wetland basins in 2005. The model was validated using 2004 data from the pulse year.

\section{Results and discussion}

\section{Dissolved oxygen in pulsing and non-pulsing hydrology}

Throughout the study period DO ranged from a morning mean low of $2.5 \mathrm{mg} \mathrm{L}^{-1}$ to a maximum evening mean high of $25.7 \mathrm{mg} \mathrm{L}^{-1}$. Dawn DO readings were significantly lower than dusk readings in each wetland $(\mathrm{p}<.001, \square=0.05$ for both), and the basins were not significantly different from each other at dawn or dusk. Diurnal variation for DO in the wetlands increased with distance from the inflow and was most pronounced in the outflow basin (Figure 2). The mean difference between dawn and dusk DO values was 2.6 $\pm 0.7 \mathrm{mg} \mathrm{L}^{-1}$ during pulses, which was significantly less ( $\mathrm{p}$ $<0.001, \square=0.05$ ) than $8.6 \pm 1.1 \mathrm{mg} \mathrm{L}^{-1}$ measured during steady flow conditions.

As expected, diurnal variation of temperature and DO were most pronounced during steady-flow periods and were significantly reduced during hydrologic pulses. The least amount of variation between dawn and dusk DO was seen during the June pulse, which had the highest hydraulic inflow of pulses observed in this study. The most extreme diurnal variation was observed the following month in July (during supplemental sampling) when wetlands were not pulsed. Zhang et al. (2005) reported similar findings for tributaries of the Upper Big Darby Creek in central Ohio, where diurnal variation of water quality parameters was dampened during flood pulses. When the experimental wetlands at the ORW were pulsed for this study, water temperatures in the wetlands were cooler and warming was less pronounced because of increased depth and turbidity in the water column. This was a direct effect of pulsing on the aquatic system, which also, in turn, contributed to reduced rates of aquatic metabolism 
a)

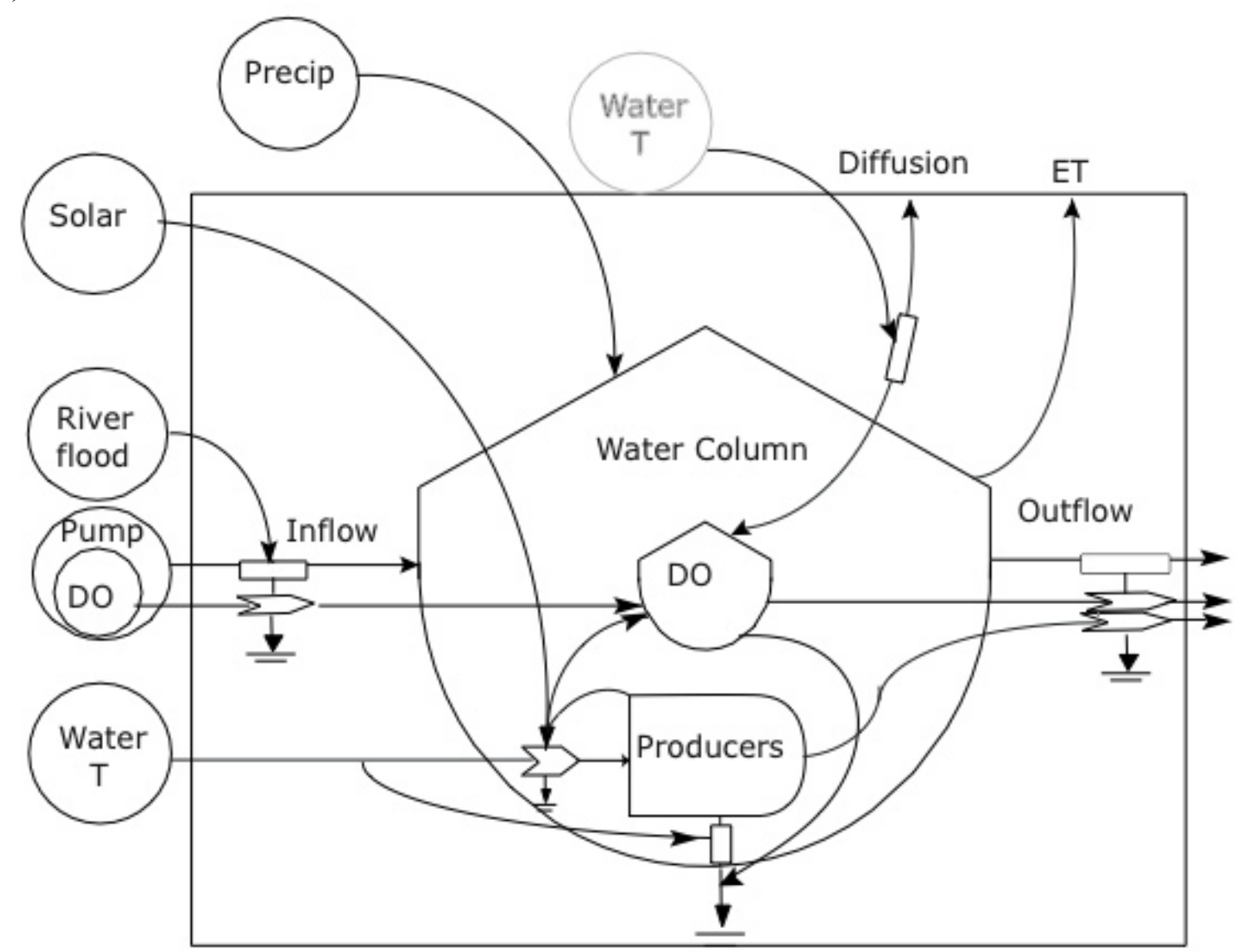

b)

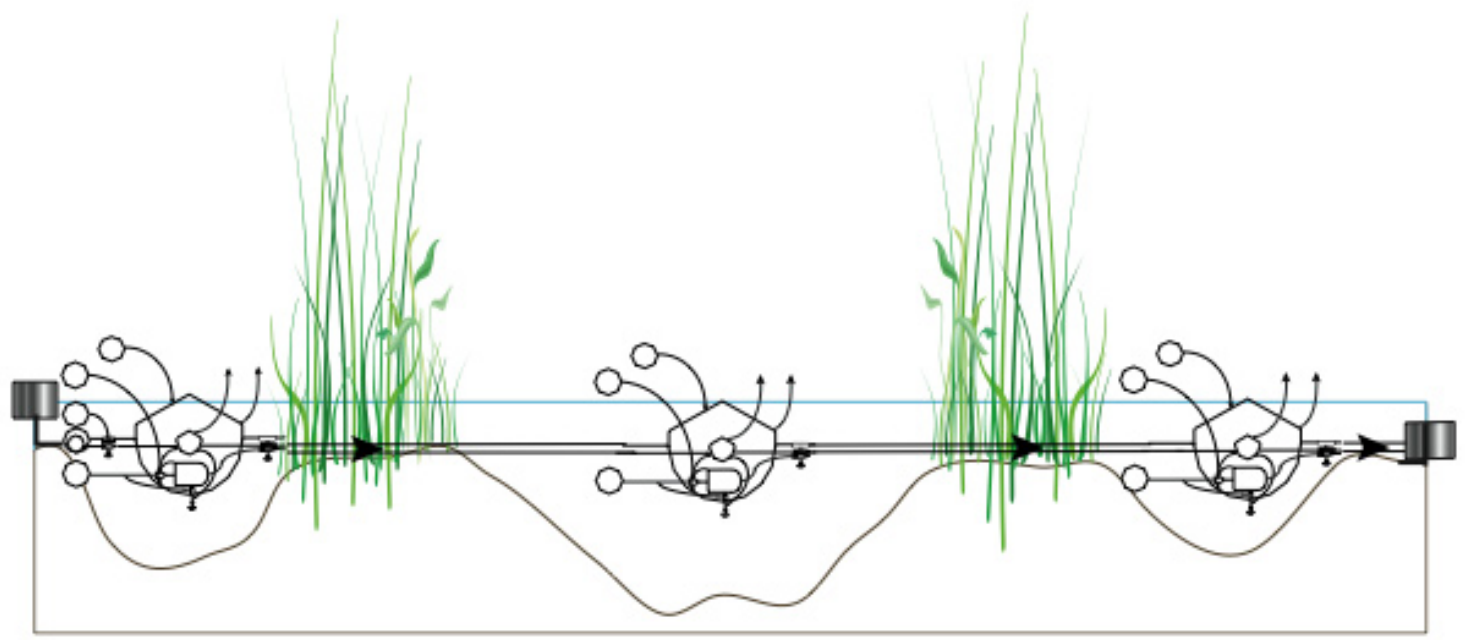

Figure 3. (a) Conceptual diagram of the simulation model developed for this project, and (b) an illustration of how the model was used to spatially represent the three "deepwater" basins in each experimental wetland. 
and less diurnal variation of DO.

During steady-flow conditions the influence of inflowing river water is apparent in the inflow basin closest to the river, where observed diurnal variation in water quality parameters was least pronounced throughout the study period. When the wetlands were pulsed, the influence extended beyond the inflow basin through the wetlands to the outflow basin. Morning dissolved oxygen below $1 \mathrm{mg} \mathrm{L}^{-1}$, which is detrimental for aquatic fauna, was seen during steady-flow conditions in the middle and outflow basins, when diurnal fluctuations of DO were most pronounced; these extreme low levels were not observed during pulses.

\section{Aquatic productivity in pulsing vs. steady-flow hydrology}

Throughout the entire study period, GPP ranged from a low of $0.5 \pm 0.1 \mathrm{kcal} \mathrm{m}^{-2} \mathrm{~d}^{-1}$, measured during the April pulse 2004 , to a maximum of $17.4 \pm 1.3 \mathrm{kcal} \mathrm{m}^{-2} \mathrm{~d}^{-1}$ measured in June 2005 during steady-flow conditions (Table 1). GPP values measured in the wetlands during this study were comparable to GPP measured at the site previously during the spring in $1997\left(7.0 \mathrm{kcal}-\mathrm{m}^{-2} \mathrm{~d}^{-1}\right)$ and $1998\left(17.2 \mathrm{kcal}-\mathrm{m}^{-2}\right.$ $\mathrm{d}^{-1}$ ) (Liptak, 2000), and were generally low, but comparable to other freshwater wetlands in the region $\left(11-21 \mathrm{kcal}^{-2} \mathrm{~m}^{-2}\right.$

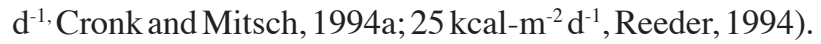
Solar efficiencies during the study period ranged from a mean low of $0.01 \pm 0.002 \%$ during the pulse in April 2004, to a mean high of $0.45 \pm 0.04 \%$ measured in June 2005, with an overall average of $0.2 \%$. These values again were generally lower but comparable to solar efficiencies reported previously for the experimental wetlands-between 0.1 and $1.06 \%$ during normal flow conditions (Yu et al., 1997; Pahys et al., 1998; Leonard et al., 2000).

GPP averaged $5.13 \pm 0.3 \mathrm{kcal}-\mathrm{m}^{-2} \mathrm{~d}^{-1}$ during pulses and was significantly lower ( $<<0.001, \square=0.05$ ) (April, May and June 2004), than GPP of $11.4 \pm 0.7 \mathrm{kcal} \mathrm{m}^{-2} \mathrm{~d}^{-1}$ measured during steady-flow conditions (April, May, and June 2005). Mean solar-normalized GPP was $0.08 \pm 0.0 \%$ of solar energy for pulses, and $0.22 \pm 0.0 \%$ for steady-flow conditions, and this difference was also significant $(\mathrm{p}<$ $0.001, \square=0.05)$. Solar-normalized GPP was lowest $(0.01 \%$ of solar energy) in April 2004 when a hydrologic pulse with a mean inflow rate of $66 \mathrm{~cm} \mathrm{~d}^{-1}$ coincided with temperatures less than $10^{\circ} \mathrm{C}$. Productivity was higher $(0.13 \%)$ during the May pulse when the mean hydrologic inflow rate was only $28 \mathrm{~cm} \mathrm{~d}^{-1}$ and temperatures were warmer. Productivity measured during draw-down conditions at the end of May prior to the June pulse was $0.14 \%$, similar to productivity observed during the May pulse earlier that month. The June pulse had an average inflow rate of $42 \mathrm{~cm} \mathrm{~d}^{-1}$, which resulted in sloughing of algal mats that had developed in the wetlands in May. During this pulse, despite warmer temperatures compared to May, aquatic metabolism was much lower $(0.10 \%)$ likely due to biomass washout. During the summer months that followed, July through September, when supplemental sampling was performed and wetlands were maintained at steady-flow, the productivity in the wetlands remained fairly constant at approximately $0.25 \%$ of solar energy.

Comparisons of GPP for pulsed versus steady-flow conditions were made for sampling periods in comparable months of April, May and June (Figure 4). In April of the

Table 1. Gross primary productivity and respiration values for each day sampled shown with solar radiation and water temperature on that day. Numbers are means \pm standard error $(n)$.

\begin{tabular}{|c|c|c|c|c|}
\hline Date sampled & Hydrology & $\begin{array}{c}\mathrm{GPP}^{\star} \\
\left(\mathrm{kcal} \mathrm{m}^{-2} \mathrm{~d}^{-1}\right)\end{array}$ & $\begin{array}{l}\text { Respiration* } \\
\left(\text { kcal m }{ }^{-2} \mathrm{~d}^{-1}\right)\end{array}$ & Solar Efficiency (\%) \\
\hline \multicolumn{5}{|c|}{ Pulse v. Steady-flow comparison } \\
\hline Apr 3-6, 2004 & Pulse & $0.5 \pm 0.1(84)$ & $0.4 \pm 0.1(84)$ & $0.01 \pm 0.002(84)$ \\
\hline May 3-5, 2004 & Pulse & $9.7 \pm 0.4(64)$ & $9.3 \pm 0.4(64)$ & $0.13 \pm 0.01(64)$ \\
\hline Jun 4-8, 2004 & Pulse & $5.9 \pm 0.3(129)$ & $6.5 \pm 0.4(129)$ & $0.10 \pm 0.01(129)$ \\
\hline Apr 4-7, 2005 & Steady-flow & $7.1 \pm 0.4(38)$ & $7.6 \pm 0.5(38)$ & $0.11 \pm 0.01(38)$ \\
\hline May 3-7, 2005 & Steady-flow & $7.9 \pm 0.6(59)$ & $8.0 \pm 0.6(59)$ & $0.10 \pm 0.01(59)$ \\
\hline Jun 1-4, 2005 & Steady-flow & $17.4 \pm 1.3(62)$ & $17.5 \pm 1.2(62)$ & $0.45 \pm 0.04(62)$ \\
\hline \multicolumn{5}{|l|}{ Summary ** } \\
\hline Apr, May \& Jun 04 & Pulse & $5.4 \pm 2.6(3)$ & $5.4 \pm 2.6(3)$ & $0.08 \pm 0.04(3)$ \\
\hline Apr, May \& Jun 05 & Steady-flow & $10.8 \pm 3.3(3)$ & $11.1 \pm 3.2(3)$ & $0.22 \pm 0.11(3)$ \\
\hline \multicolumn{5}{|c|}{ Supplemental Sample Periods } \\
\hline May 23-24, 2004 & draw-down & $8.8 \pm 1.2(18)$ & $9.1 \pm 1.3(18)$ & $0.14 \pm 0.02(18)$ \\
\hline Jul 10-13, 2004 & Steady-flow & $14.8 \pm 1.8(38)$ & $13.5 \pm 1.8(38)$ & $0.25 \pm 0.03(38)$ \\
\hline Aug 17-19, 2004 & Steady-flow & $10.8 \pm 1.7(20)$ & $11.1 \pm 1.7(20)$ & $0.25 \pm 0.04(20)$ \\
\hline Sep 13-16, 2004 & Steady-flow & $12.1 \pm 1.1(42)$ & $11.8 \pm 1.1(42)$ & $0.27 \pm 0.03(42)$ \\
\hline
\end{tabular}

* Any values of R or GPP less than zero were assumed to be zero

${ }^{* *}$ Normalized for varying sample sizes by taking the mean of the monthly means 
steady-flow year 2005, solar efficiency was significantly greater than in the pulsing year 2004 ( $<<0.001, \square=0.05$; Figure 4). This difference can be explained in part by the temperature difference since average water temperature was approximately $5^{\circ} \mathrm{C}$ warmer in 2005 . For the May sampling period, the reverse was found, with productivity measured in the steady-flow year significantly lower than productivity in the pulse year $(\mathrm{p}=0.001, \square=0.05)$, despite warmer water temperatures in 2005. The pulse may have enhanced aquatic metabolism in this month, when inflow rates were moderate, compared to pulse rates in April and June. For June, mean productivity measured in $2005(0.45 \%)$ was 4.5 times higher than that measured in $2004(0.10 \%)$, with average temperature virtually the same for both years. The extreme difference in productivity observed in this month indicates that productivity was negatively affected by the pulsed hydrology. Higher productivity in June of 2005 was possible because a lack of hydrologic pulses in the previous month allowed more biomass to be present in the system at the time of sampling.

\section{Aquatic productivity vs. hydrologic flux}

When mean daily solar-corrected gross primary productivity was plotted as a function of the daily inflow rate, productivity appears to decrease exponentially with increased flow rate (Figure 5; $\mathrm{R}^{2}=0.41$ ). The highest GPP observed during the study period occurred at moderate steady inflow rates, indicating that moderate flow rates can increase productivity. GPP was also more variable at moderate flow rates, indicating that other environmental factors such as water temperature, nutrient levels or species composition influence productivity in the system when hydrology is not pulsing.

\section{Combined effects of hydrologic pulsing and temperature}

When GPP is plotted as a function of water temperature (Figure 6) for pulsed and steady flow sample periods $\mathrm{t}$ followed a common Shelford-type limitation curve, increasing with increased temperature to an optimum point after which GPP was limited by increasing temperature. During steady-flow conditions, temperatures were warmer and a higher maximum productivity was achieved. The curve for pulsed conditions was shifted to the left with a lower optimum temperature for productivity. Because different species have unique optimum temperatures for growth, the difference between these two curves may indicate that different species dominated primary productivity during pulses versus steady-flow.

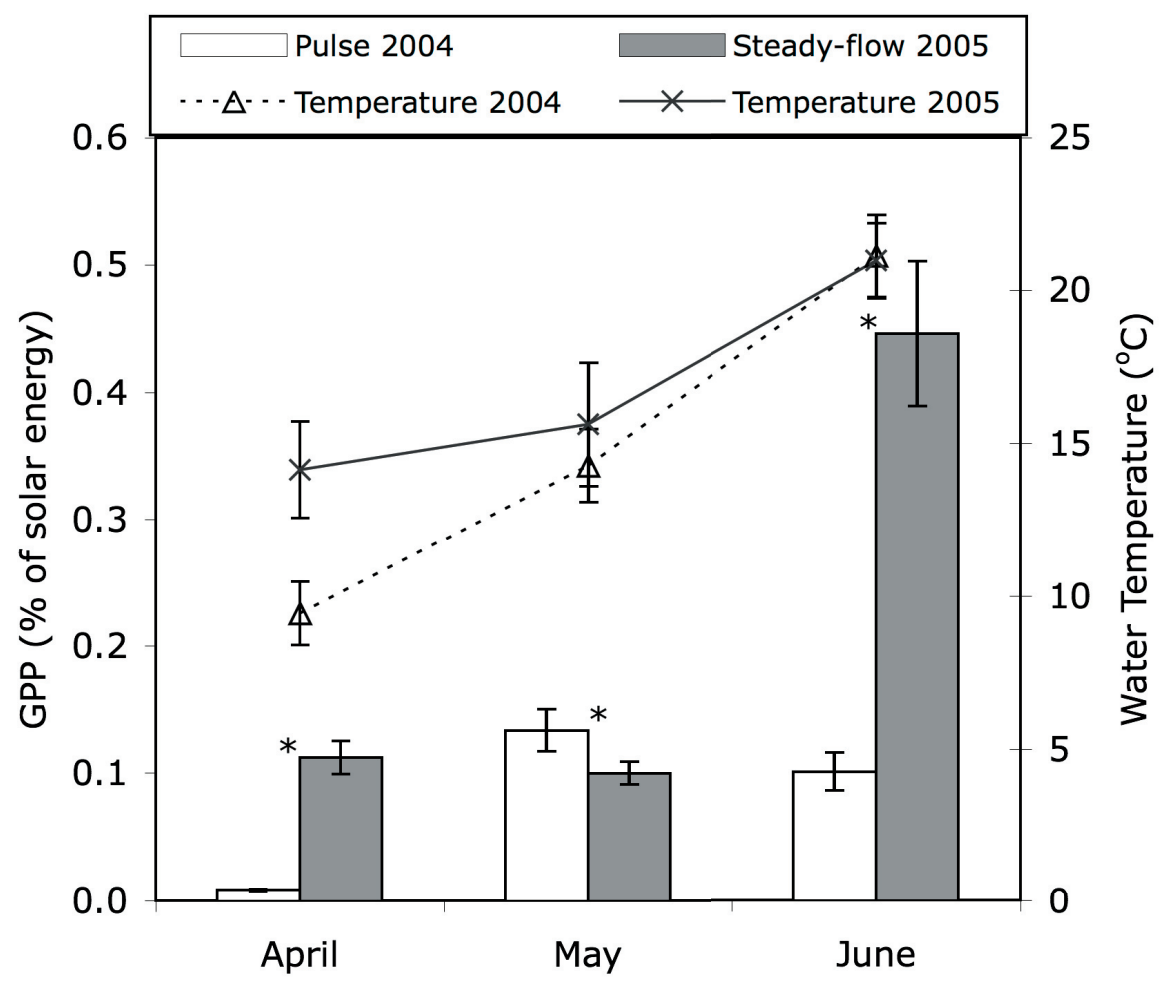

Figure 4. Solar-corrected gross primary productivity (GPP) and average water temperature for the pulse year 2004 and steady-flow year 2005. Error bars indicate standard error. The * indicates a significant difference between 2004 and 2005 GPP for that month according to ANOVA at the 0.05 significance level 


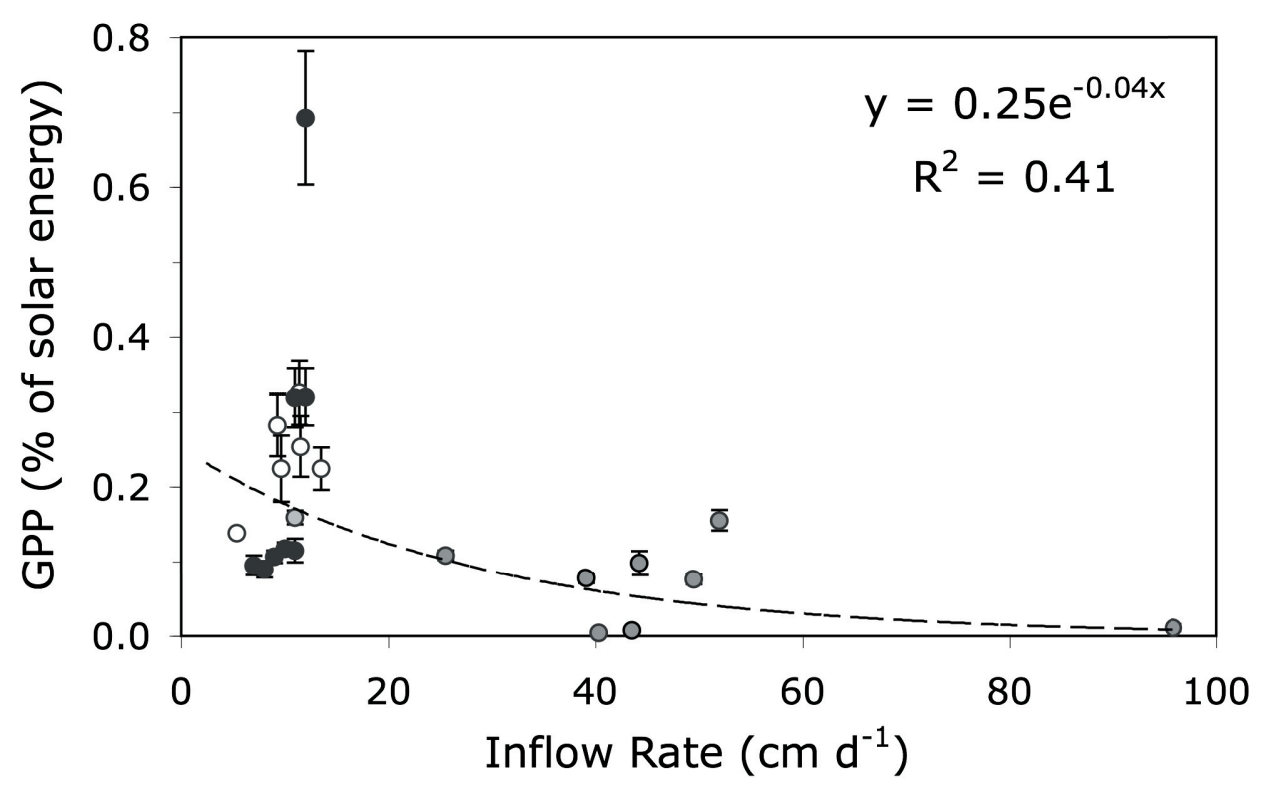

Figure 5. Solar-corrected gross primary productivity (GPP) as a function of the hydraulic loading rate for all days sampled. Black circles indicate steady-flow conditions, light grey circles indicate pulsed conditions and white circles indicate supplemental sample days. Error bars indicate standard error.

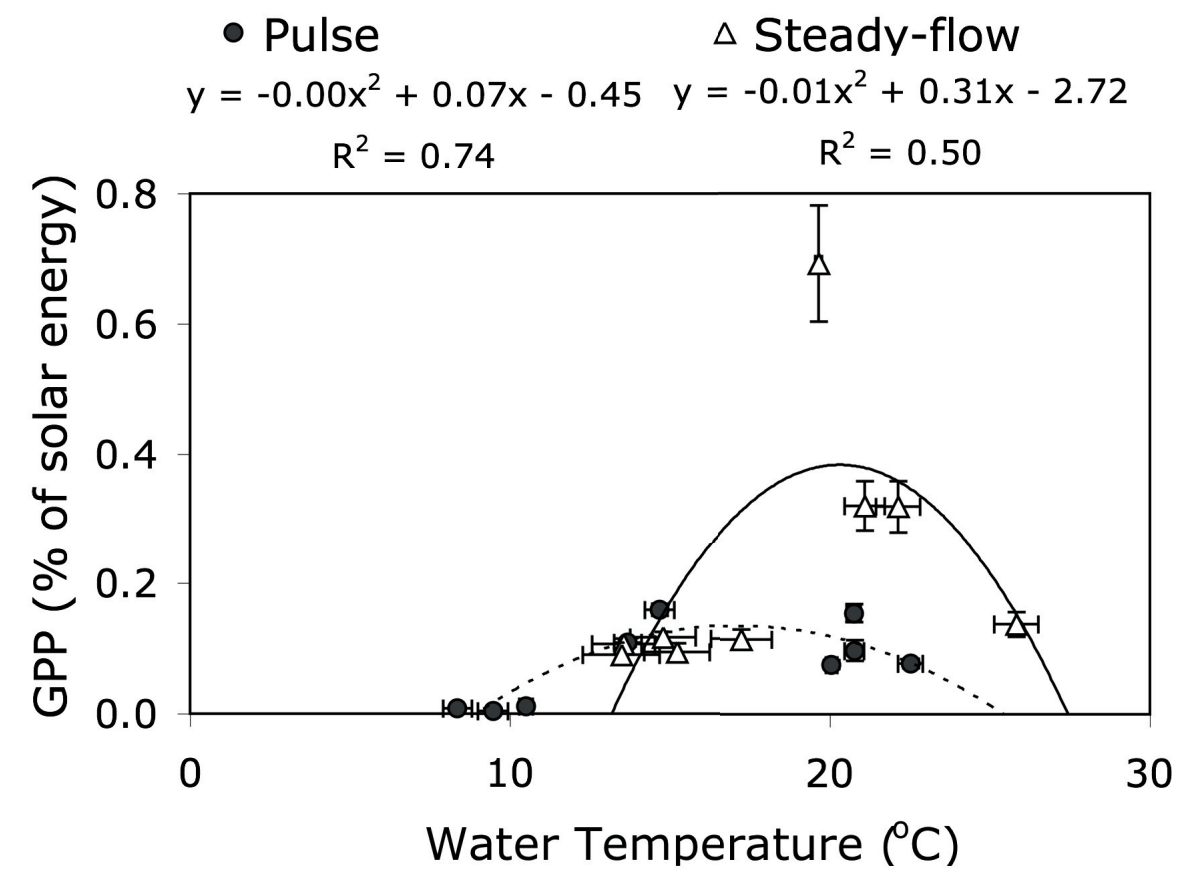

Figure 6. Solar-corrected gross primary productivity (GPP) as a function of water temperature for pulsed and steadyflow conditions in April, May and June. Points are the mean value for a sample day with bars for standard error. 
a)

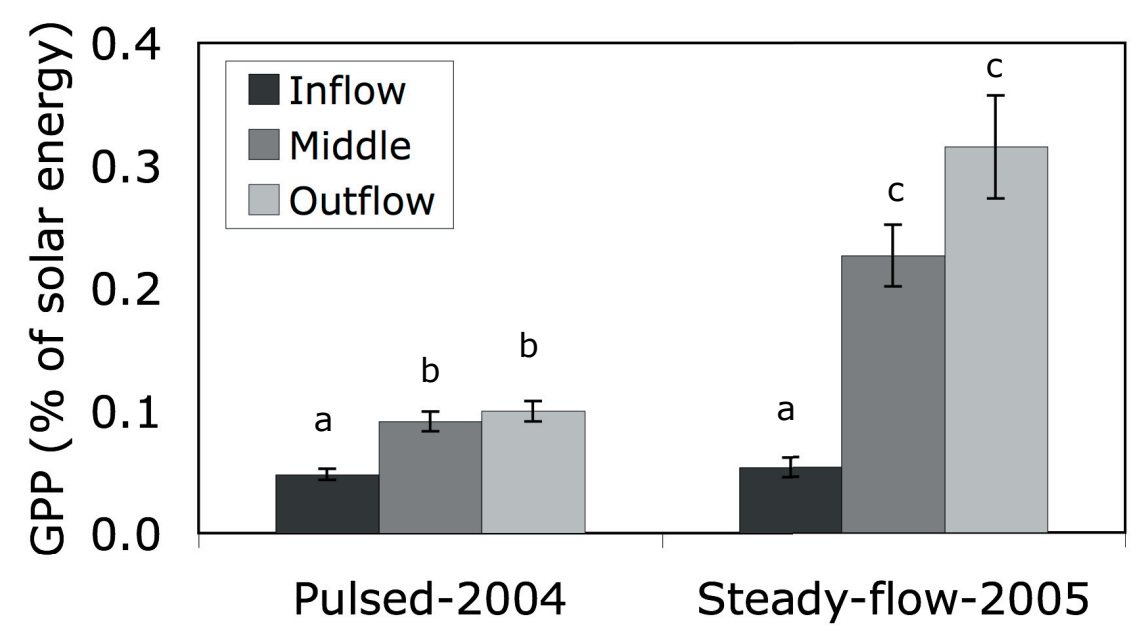

b)

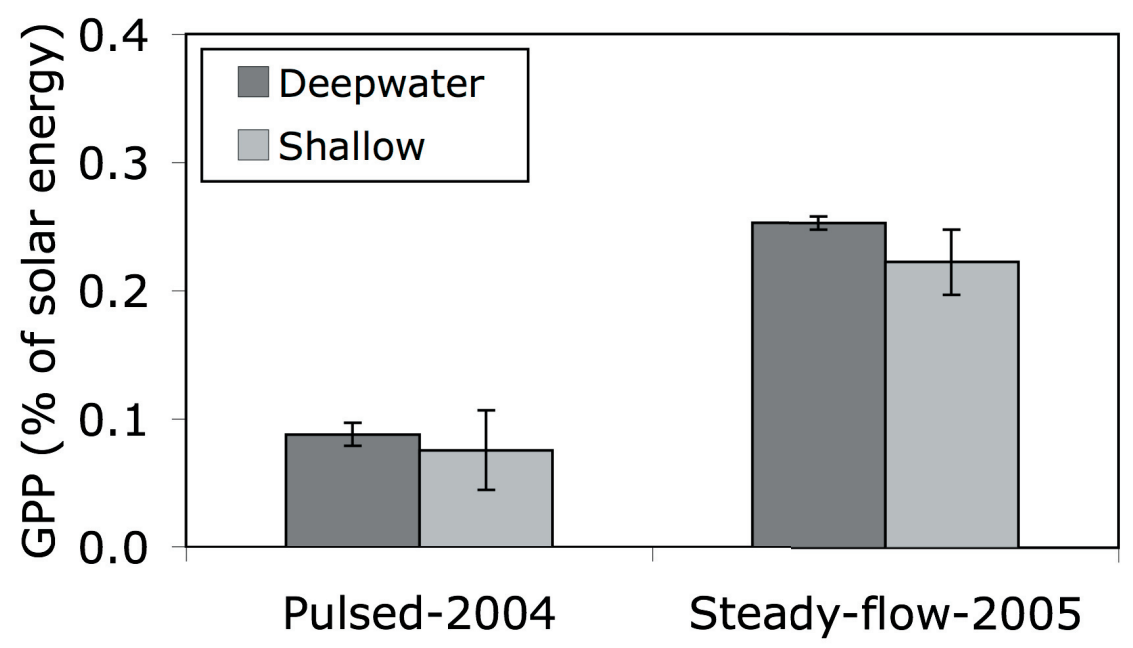

Figure 7. Solar-corrected gross primary productivity (GPP) for (a) inflow, middle, and outflow basins during and (b) deepwater vs. shallow sites during pulsing and steady-flow conditions. Different letters indicate significant difference between means according to ANOVA at the 0.05 significance level.

\section{Inflow-outflow and shallow-deep gradients}

Two gradients existed in these experimental wetlands. A "longitudinal" gradient exists from inflow to outflow where nutrient concentrations decrease and localized turbulence caused by the inflow decreases with distance from the inflow. A "transverse" gradient also existed in the wetlands from middle to edge where water depth decreases. Along the longitudinal gradient, GPP was lowest in the inflow basin for both pulsed and steady flow conditions and increased with distance from the inflow pipe (Figure 7a). The inflowing river water creates turbulence in this basin, and this pattern of increased GPP with distance from the inflow has been observed previously in the experimental wetlands by Liptak (2000) and Leonard et al. (2000). GPP appears to be highest in the outflow basin during steady-flow conditions, however variability between the middle and outflow basins was not statistically significant. This suggests that productivity in the outflow basin was not limited by low nutrient availability, which may occur when a nutrient gradient develops from inflow to outflow (Liptak, 2000). The rates of inflow maintained during this study for steady-flow conditions may have been high enough that metabolism was not nutrient limited in the outflow basin.

In other riparian wetland ecosystems, flood pulses have been shown to decrease spatial variability of water quality parameters (Bayley et al., 1985; Sabo et al., 1999). While it appeared this this may have occurred in the experimental wetlands during this study to a small extent (Figure 7b), the impact of pulsing in the transverse gradient from deepwater to shallow water was insignificant. Where water depth 
was shallow, there was compensation by the water column producers with higher volumetric productivity. Productivity did not appear to be limited by water depth.

\section{Model calibration and validation}

The model shown in Figure 3a was designed to integrate the hydrology, dissolved oxygen, and productivity described above. The hydrology submodel was initially calibrated using steady-flow data from June of 2005. Outflow coefficients were established to give the wetlands a total detention time of approximately 1.2 days, according to site data. When evaluating model performance based on the $\%$ difference between model and actual values (determined by subtracting the actual value from model prediction and then dividing by actual value and multiplying by 100) the model performs well (Table 2). The aquatic metabolism submodel was calibrated with data collected during the steady-flow year the first week of June 2005. Inflow basins were excluded from the calibration process because of the unique characteristics in that basin due to localized turbulence around the inflow. The model output for each individual basin was compared to average GPP measured in each basin (Figure 8). The model predicted GPP patterns and generally was within $10 \mathrm{kcal} \mathrm{m}^{-2} \mathrm{~d}^{-1}$ of measured GPP.
When the model was evaluated based on the average for all six basins compared to average data measured in all six basins, model predictions of GPP were on average within $25 \%$ of actual values, and were within one standard deviation of actual values $88 \%$ of the time (Table 2 ). The dissolved oxygen submodel had a lower agreement between model output and actual data (Figure 9) with an average percent difference between model and data values greater than $20 \%$ (Table 2).

The model was validated using data from the pulsing year for March through September 2004. The model handled hydrologic pulses well and predicted water levels on average within 14 and $17 \%$ of actual values for $\mathrm{W} 1$ and W2, respectively (Table 2). Productivity was reasonably predicted by the metabolism submodel for June through September 2004, but was underestimated during pulsing months March through May, especially in the inflow basin (Figure 10). Following the May pulse, GPP was overestimated during steady-flow conditions. Drawdown conditions may have limited productivity at this time (Cronk and Mitsch, 1994a; Mosisch and Bunn, 1997). Comparison of the model output of daily mean DO to actual continuous data is shown in Figure 11. As was seen during calibration of this submodel, performance was generally lowest for the

Table 2: Summary table of model output compared to actual data using three different methods: $\mathrm{R}^{2}$-which represents correlation between model output and data based on a linear trend line; percent of time that the model was within one standard deviation (SD) of data values; and average of the absolute value of the difference between model output and data.

Submodel $\quad R^{2} \quad$ Percent of time difference $\leq 1 \mathrm{SD} \quad$ Average difference (\%)

\begin{tabular}{lcccccc}
\hline & W1 & W2 & W1 & W2 & W1 & W2 \\
\hline Hydrology Submodel & & & & & & \\
Calibration & 0.2 & 0.3 & 48 & 32 & $11^{*}$ & $13^{*}$ \\
Validation & 0.8 & 0.7 & 88 & 89 & $14^{*}$ & $17^{*}$ \\
Productivity Submodel & & & & & &
\end{tabular}

\begin{tabular}{|c|c|c|c|c|c|c|}
\hline \multicolumn{7}{|l|}{ Calibration } \\
\hline Inflow basin & 0.02 & 0.11 & 75 & 100 & 274 & 121 \\
\hline Middle basin & 0.39 & 0.44 & 88 & 88 & 31 & 28 \\
\hline Outflow basin & 0.59 & 0.53 & 88 & 75 & 23 & 39 \\
\hline Both wetlands** & \multicolumn{2}{|c|}{0.56} & \multicolumn{2}{|c|}{88} & \multicolumn{2}{|c|}{25} \\
\hline \multicolumn{7}{|l|}{ Validation } \\
\hline Inflow basin & 0.02 & 0.10 & 53 & 33 & 130 & 150 \\
\hline Middle basin & 0.20 & 0.50 & 67 & 60 & 65 & 78 \\
\hline Outflow basin & 0.60 & 0.20 & 67 & 60 & 40 & 95 \\
\hline Both wetlands** & \multicolumn{2}{|c|}{0.60} & \multicolumn{2}{|c|}{80} & \multicolumn{2}{|c|}{48} \\
\hline \multicolumn{7}{|c|}{ Dissolved Oxygen Submodel } \\
\hline Calibration & 0.01 & 0.11 & 62 & 48 & 28 & 21 \\
\hline Validation & 0.01 & 0.11 & 58 & 61 & 34 & 57 \\
\hline
\end{tabular}

\footnotetext{
* Based on water depth, predicted by the model and measured in the wetlands, not water level elevation.

** Based on the average of model output for all basins, compared to average data for all basins in both wetlands.
} 

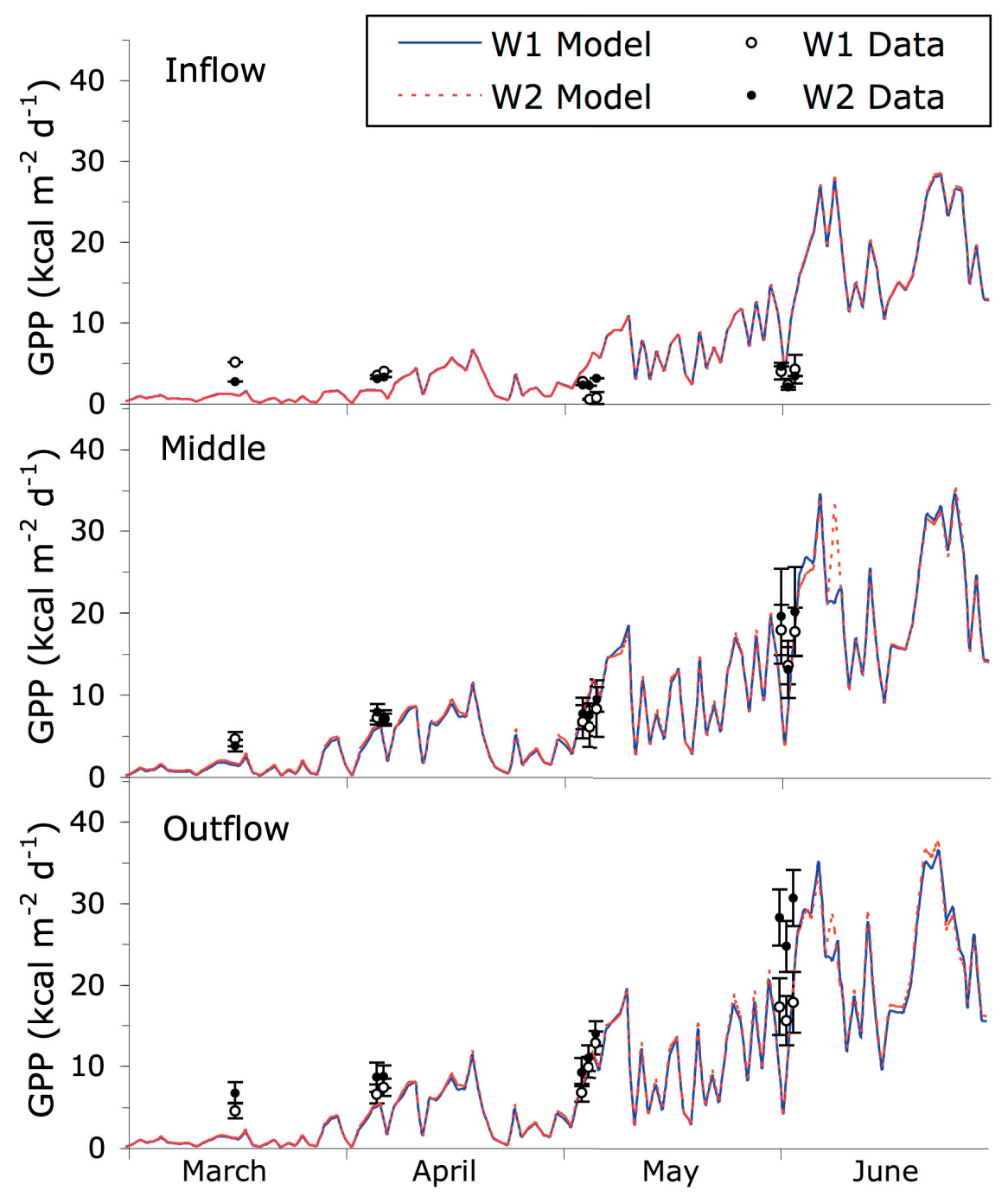

Figure 8. Model calibration showing prediction of gross primary productivity (GPP) compared to field data for 2005 in the inflow, middle and outflow basins of Wetland 1 and Wetland 2. Data points represent daily average GPP measured using with standard error bars.

three model evaluation methods as summarized in Table 2 but the model simulated dissolved oxygen within a reasonable range despite extreme fluctuations of dissolved oxygen on a diurnal basis.

\section{Model simulations}

Fourteen alternative simulations were run on the validated model to further investigate the effect of hydrologic pulsing on aquatic metabolism (Table 3; Figure 12). First, the model was used to calculate total biomass production for March through June to compare total production between the steady-flow year 2005 (Simulation 1) and the pulsing year 2004 (Simulation 2). During these months total water volume inflows were 23 and $24 \mathrm{~m}$ in 2004, and 16 and 18 $\mathrm{m}$ for 2005 in W1 and W2, respectively. The average of total production $\left(\mathrm{kcal} \mathrm{m}^{-2}\right)$ for both wetlands during these months was approximately $43 \%$ lower when the wetlands experienced hydrologic pulses (Figure 12a). This simulation result supports findings from the field study that the overall effect of hydrologic pulsing was negative on aquatic metabolism.

The validated model for 2004 was then used as a base case and revised by simulating steady-flow hydrology from 2005 (Simulation 3; Figure 12a). With steady-flow hydrology the model predicted production for 2004 that was only $7 \%$ lower than model prediction of total production for 2005. Because the pulses had an effect on water temperature in the wetlands reducing overall temperatures and dampening diurnal temperature variation, the base case model was then simulated using 2005 inflow rates and 2005 water temperature data (Simulation 4). This resulted in a $2 \%$ increase in total production from Simulation 3, and 62\% more production than for the base case. The model was then simulated with steady flow hydrology using 2005 inflow rates and 2005 solar radiation data to investigate if 


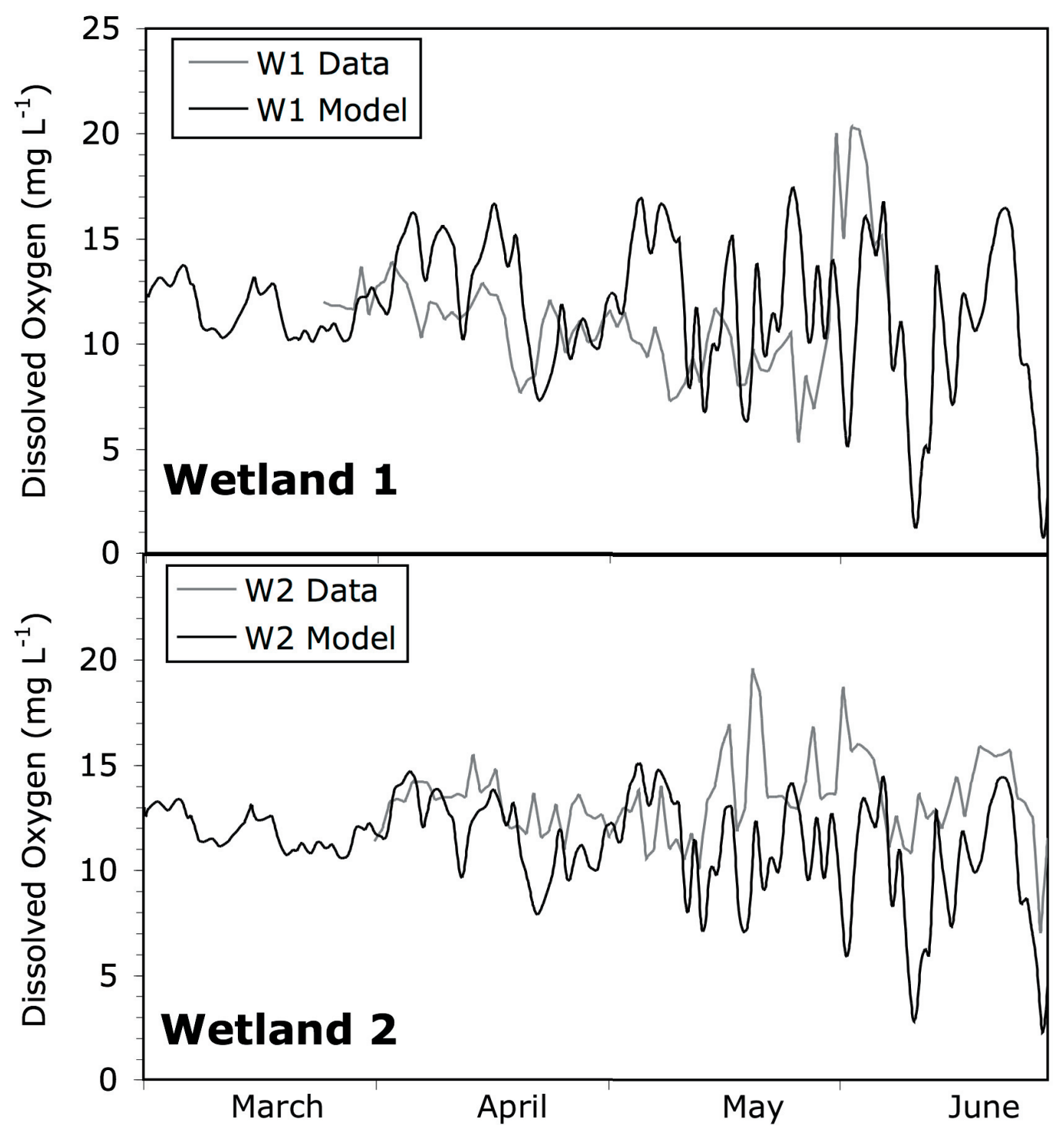

Figure 9. Model calibration showing mean daily dissolved oxygen (DO) predicted by the model for the outflow basin during the calibration year 2005 compared to actual DO measured for the outflow of Wetland 1 and Wetland 2.

the difference in total production was the result of different solar energy inputs between the two years (Simulation 5). This resulted in $60 \%$ more production than the base case, indicating that the model was relatively insensitive to this change. These three simulations for the 2004 model with steady-flow hydrology show that much of the difference in productivity predicted by the model for 2005 and 2004 was attributable to the different hydrologic regime.

Additional simulations were then run with varying degrees of pulse magnitudes, while between-pulse flow rates were left unchanged (Simulations 6-9; Figure 12b). The highest total production was achieved by the model when inflow rates were $80 \%$ of actual values $\left(27 \mathrm{~cm} \mathrm{~d}^{-1}\right)$. When the pulse inflow rate increased from 27 to $40 \mathrm{~cm} \mathrm{~d}^{-1}$, total production decreased by $10 \%$ for $\mathrm{W} 1$ and by $12 \%$ for $\mathrm{W} 2$. Increasing pulse magnitudes by $20 \%$ to $48 \mathrm{~cm} \mathrm{~d}^{-1}$ caused a $3 \%$ reduction in production, while pulse magnitudes at $200 \%$ of actual values $\left(80 \mathrm{~cm} \mathrm{~d}^{-1}\right)$ only reduced production by an additional $3 \%$. From these simulations and results of the field study, it appears that the flow threshold for these wetlands where metabolism becomes negatively affected is between 30 and $50 \mathrm{~cm} \mathrm{~d}^{-1}$. For a shallow wetland approximately $30 \mathrm{~cm}$ deep this is equivalent to a turnover time of 0.6 to 1.0 day.

The k-value determining biomass washout during 


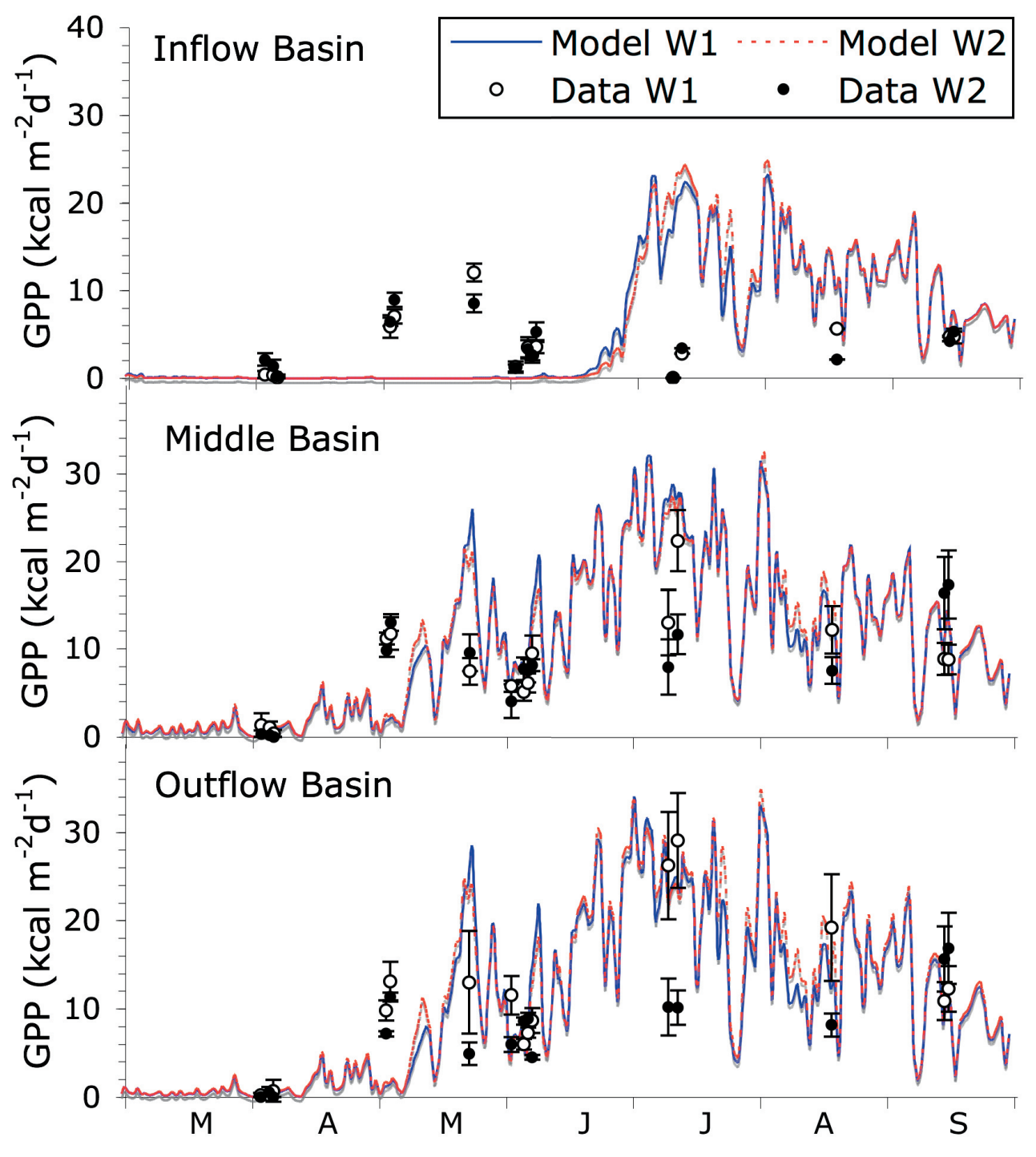

Month

Figure 10. Model validation showing predicted gross primary productivity (GPP) for the inflow, middle and outflow basins of both experimental wetlands for pulsing year 2004. Data points are the average GPP measured in each basin using spatial diurnal dissolved oxygen readings with standard error bars. 


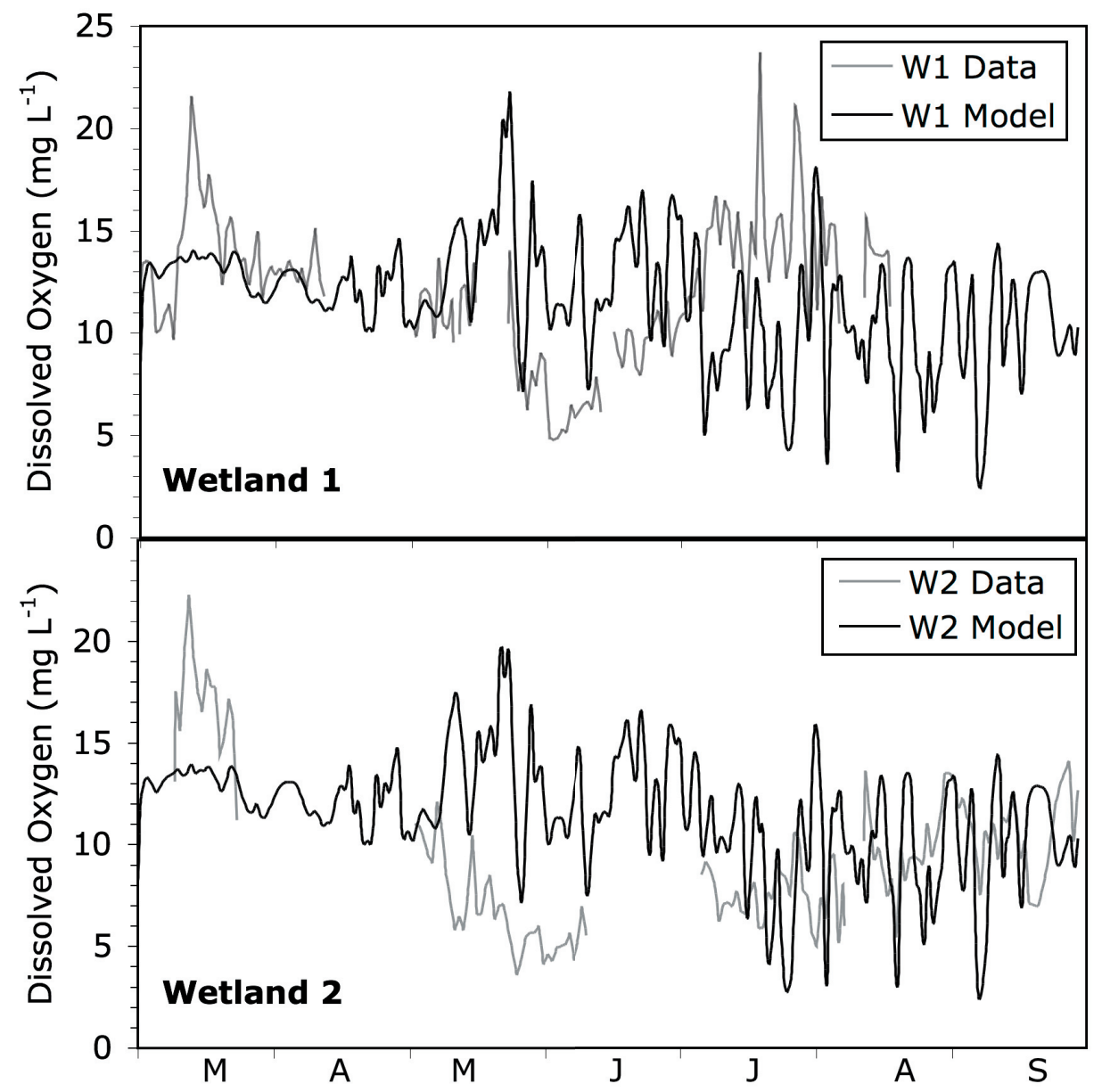

Figure 11. Model validation showing dissolved oxygen (DO) predicted by the model for the outflow basin during the validation year 2004, and actual DO measured for the outflow of Wetland 1 and Wetland 2.

Table 3. Description of model simulations

Simulation number Description

Calibration

1

Validation

2
Calibration of the model with data from steady-flow year, 2005

Validation of the model with data from the pulsed year, 2004. Referred to as the "Base Case" in text and figures.

Steady-flow Simulations with Validated model 3

4

5

Pulsed Simulations

6-9

$10-14$
2005 steady-flow inflow rates used in place of 2004 inflow rates. 2005 inflow rates and water temperature used in place of 2004 data. 2005 inflow rates and solar radiation used in place of 2004 data.

Pulse amplitude varied at $60,80,120$, and $200 \%$ of 2004 base case pulses Model run with 5 different values for biomass export or scouring coefficient - k6: : $0.01,0.05,0.1,0.5,1.0$ 

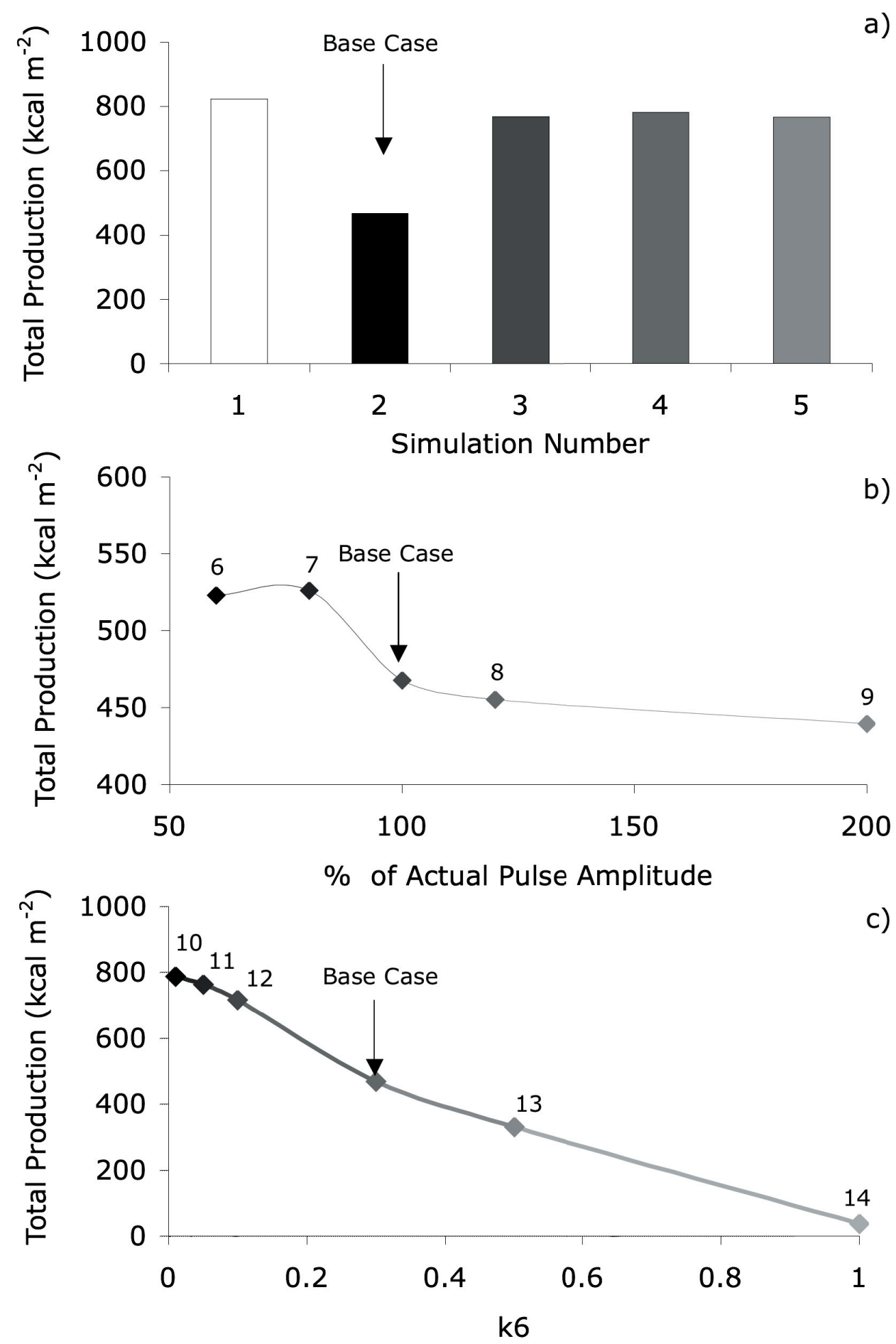

Figure 12. Model simulation results after validation of total primary production (a) for the following simulations (March through June) comparing experimental conditions: 1. Model calibration (2005 steady-flow conditions) 2. Model validation and base case (2004 pulsing conditions) 3. Base case (2004) with pulses removed (2005 flow imposed) 4. Base case (2004) with pulses removed (2005 flow imposed) and 2005 water temperature added 5. Base case (2004) with pulses removed, 2005 flow imposed, 2005 water temperature added, and 2005 solar radiation added. (b) Simulations of total productivity with pulse amplitude changed by $60 \%$ (Simulation 6 ), $80 \%$ (Simulation 7), 120\% (Simulation 8) and 200\% (Simulation 9) of 2004 base-case conditions for the simulation period from March through June. Assigned simulation numbers are shown above line. (c) Total production simulated by the model for base case (2004 data) for the entire simulation period from March through September, as a function of the export coefficient (k6) that controls biomass export during hydrologic pulses. Simulations were run for five values of k6 in addition to the validated base case (0.3). Assigned simulation numbers are shown above line. 
hydrologic pulses (k6) was simulated at five different levels, $0.01,0.05,0.1,0.5$, and 1.0 (Simulations 10-14; Figure 12c). As expected, increasing this coefficient leads to more biomass export and therefore negatively impacts the total production in the system. Increasing $\mathrm{k} 6$ by two orders of magnitude (from $0.01-1.0$ ) resulted in a $60 \%$ reduction in total production for the months simulated.

\section{Conclusions}

The variability of flow rates during pulses resulted in different effects on aquatic metabolism for each pulse event. Field data and the ecosystem model developed for this project provided insight into complicated interactions of stimulatory and inhibitory affects of pulsing on aquatic metabolism.

1. Increased flow rates during hydrologic pulses reduced diurnal variation of temperature and DO.

2. Hydrologic pulses with ample magnitude produced immediate negative effects on aquatic metabolism, while pulses with moderate inflow rates enhanced productivity.

3. When hydrologic pulses also cause cooler water temperatures, aquatic metabolism is even further reduced. When flood pulses coincided with cold temperatures $\left(<10^{\circ} \mathrm{C}\right)$, wetland aquatic productivity was almost completely suppressed.

4. Results from both the field study and model simulations suggest that the threshold inflow rate where aquatic metabolism begins to be negatively affected is between 30 and $50 \mathrm{~cm} \mathrm{~d}^{-1}$. For a shallow wetland (average $30-\mathrm{cm}$ deep) this is equivalent to a wetland turnover time of 0.6 to $1.0 \mathrm{~d}$.

5. Simulations with the ecosystem model extended the capability to compare multi-year, whole ecosystem experiments that otherwise would be difficult to compare.

6. Field research investigating the effect of flow rate on biomass export would be helpful for development of more accurate models of aquatic productivity in systems with variable hydrology.

7. Whole ecosystem experiments investigating controlled variation across a wide range of pulse amplitudes would help to determine optimum flow rates and critical thresholds for aquatic primary productivity in wetlands.

8. Additional research is needed to help quantify short term, and potential long-term, positive effects of seasonal pulses on aquatic metabolism.

9. The dynamic ecosystem model developed for this research proved invaluable for making a comparison of ecosystem function across years in order to analyze the effect of hydrologic pulsing. Using the simulation model it was possible to integrate multiple variables of solar radiation, temperature and hydrology that influence GPP into one systems view, where each could be manipulated. It was possible to run the model with multiple combinations of input data from the different years and to examine the result on total aquatic production. Without this integration, drawing conclusions from an indicator such as GPP, which rapidly changes in a flow-through system, would be extremely difficult.

\section{References}

Altor, A. E. and W.J. Mitsch. 2006. Methane flux from created wetlands: Relationship to intermittent versus continuous inundation and emergent macrophytes. Ecological Engineering in press

Anderson, C.J. and W.J. Mitsch. 2006. Sediment, carbon, and nutrient accumulation at two 10-year-old created riverine marshes. Wetlands in press

Anderson, C.J., W.J. Mitsch, and R.W. Nairn. 2005. Temporal and spatial development of surface soil conditions at two created riverine marshes. Journal of Environmental Quality 34: 2072-208

Bayley, S.E., Zoltek, J., Jr., Hermann, A.J., Dolan, T.J. and Tortora, L., 1985. Experimental manipulation of nutrients and water in a freshwater marsh: effects on biomass, decomposition, and nutrient accumulations. Limnology and Oceanography 30: 500-512.

Buzzelli, C.P., Childers, D.L., Dong, Q. and Jones, R.D., 2000. Simulation of periphyton phosphorus dynamics in Everglades National Park. Ecological Modelling 134:103-115.

Carr, G.M., Duthie, H.C., Taylor, W.D., 1997. Models of aquatic plant productivity: a review of the factors that influence growth. Aquatic Botany 59: 195-215.

Christensen, N., Mitsch, W.J. and Jorgensen, S.E., 1994. A first generation ecosystem model of the Des Plaines River experimental wetlands. Ecological Engineering 3: 495-521.

Cronk, J.K. and Mitsch, W.J., 1994a. Aquatic metabolism in four newly constructed freshwater wetlands with different hydrologic inputs. Ecological Engineering 3: 449-468.

Deal, R. and Kantz, J.A., Jr., 1997. Composition and population dynamics of floating algal mats in constructed wetlands. In: Mitsch, W.J., ed.. Olentangy RiverWetland Research Park at The Ohio State University, Columbus, $\mathrm{OH}, \mathrm{pp} 153$ - 154.

Goldsorough, L.G., Robinson, G.G.C., 1996. Pattern in Wetlands. In: R.J. Stevenson, M.L. Bothwell and R.L. Lowe (Editors) Algal Ecology: Freshwater Benthic ecosystems. Academic Press. New York, NY. pp 77117.

Harter, S.K. and W.J. Mitsch. 2003. Patterns of short-term sedimentation in a freshwater created marsh. Journal of Environmental Quality. Journal of Environmental Quality 32: 325-334.

Hernandez, M.E. and W.J. Mitsch. 2006. Influence of hydrologic pulses, flooding frequency, and vegetation on nitrous oxide emissions from created riparian marshes. 
Wetlands in press

ISEE Systems Inc., formerly High Performance Systems, Inc. 2003. STELLA $®$ Software Version 8.1 for Power Macintosh. Copyright (C1985 - 2003. www.hps-inc. com. Lebanon, NH.

Kantz, J., Jr. and Deal, R., 1999. Comparison of macroalgal dominants in the two Olentangy River experimental wetland basins. In: Mitsch, W.J. and V. Bouchard (Editors). Olentangy River Wetland Research Park at The Ohio State University, Annual Report 1998. Columbus, OH. pp 77-78.

LI-COR Biosciences, 2005. Environmental division. LI200SA silicon photovoltaic detector. www.li-cor.com. Lincoln, NE, USA.

Liptak, M.A., 2000. Water column productivity, calcite precipitation, and phosphorus dynamics in freshwater marshes. Ph.D. Dissertation, The Ohio State University, Columbus, OH. 161 pp.

Leonard, N.J., Wang, L. and Mitsch, W.J., 2000. Gross primary productivity and aquatic plant biomass: indicators of divergence in two constructed wetlands. In: Mitsch, W.J. and X. Wu. (Editors), Olentangy River Wetland Research Park at The Ohio State University, Annual Report 1999. The Ohio State University, Columbus, OH. pp. 69-76.

Metzker, K.D. and Mitsch, W.J., 1997. Modelling self-design of the aquatic community in a newly created freshwater wetland. Ecological Modelling. 100: 61-86

Mitsch, W.J. and Reeder, B., 1991. Modelling nutrient retention of a freshwater coastal wetland: Estimating the roles of primary productivity, sedimentation, resuspension and hydrology. Ecological Modelling 54: 151-187.

Mitsch, W.J., X. Wu, R.W. Nairn, R.E. Weihe, N. Wang, R. Deal and C.E. Boucher. 1998. Creating and restoring wetlands: A whole-ecosystem experiment in self-design. BioScience 48: 1019-1030.

Mitsch, W.J. and Gosselink, J.G., 2000. Wetlands, 3rd Ed. John Wiley and Sons, New York. 920 pp.

Mitsch, W.J. and Wang, N., 2000. Large-scale coastal wetland restoration on the Laurentian Great Lakes: Determining the potential for water quality improvement. Ecological Engineering 15: 267-282.

Mitsch, W.J., Wang, N., Zhang, L., Deal, R., Wu, X. and Zuwerink, A., 2005a. Using ecological indicators in a whole ecosystem experiment. In: S.E. Jorgensen, R. Costanza and F.L. Xu (Editors). Handbook of Ecological Indicators for Assessment of Ecosystem Health. CRC Press, Boca Raton, FL.

Mitsch, W.J., L. Zhang, C.J. Anderson, A. Altor, and M. Hernandez. 2005b. Creating riverine wetlands: Ecological succession, nutrient retention, and pulsing effects. Ecological Engineering 25: 510-52.
Nahlik, A.M. and W.J. Mitsch. 2006. The effects of river pulsing on sedimentation in created riparian wetlands In: W.J. Mitsch, L. Zhang, C. L. Tuttle, and K. Jones (Editors). Olentangy River Wetland Research Park at the Ohio State University, Annual Report 2005. The Ohio State University, Columbus, OH, pp. 45-62.

Nairn, R.W. and W.J. Mitsch. 2000. Phosphorus removal in created wetland ponds receiving river overflow. Ecological Engineering 14: 107-12.

Mosisch, T.D., Bunn, S.E., 1997. Temporal patterns of rainforest stream epillithic algae in relation to flow-related disturbance. Aquatic Botany 58:181-193.

Odum, H.T. and Hoskin, C.M., 1958. Comparitive studies of the metabolism of marine waters. Public Institute of Marine Science, University of Texas 5: 16-46.

Pahys, K.E., Bouchard, V. and Mitsch, W.J., 1998. Water column primary productivity in the experimental freshwater wetlands for July and October 1997. In: W.J. Mitsch and V. Bouchard (Editors). Olentangy River Wetland Research Park at the Ohio State University, Annual Report 1997. The Ohio State University, Columbus, OH, pp. 149-153.

Peterson, C.G., 1996. The role of periphyton in benthic foodwebs. In: R.J. Stevenson, M.L. Bothwell and R.L. Lowe (Editors) Algal Ecology: Freshwater Benthic ecosystems. Academic Press. New York, NY. pp 533-572.

Reeder, B.C., 1990. Primary productivity, sedimentation, and phosphorus cycling in Lake Erie coastal wetland. Ph.D. Dissertation, The Ohio State University, Columbus, OH. 161 pp.

Reeder, B.C., 1994. Estimating the role of autotrophs in nonpoint source phosphorus retention in the Laurentian Great Lakes coastal wetland. Ecological Engineering 3: 161-169.

Sabo, M.J., Bryan, C.F., Kelso, W.E. and Rutherford, D.A., 1999. Hydrology and aquatic habitat characteristics of a riverine swamp: Influence of flow on water temperature and chemistry. Regulated Rivers: Research and Management 15: 505-523.

Spieles, D.J. and Mitsch, W.J., 2000. The effects of season and hydrologic and chemical loading on nitrate retention in constructed wetlands: a comparison of low- and highnutrient riverine systems. Ecological Engineering 14: 77-91.

Spieles, D.J. and Mitsch, W.J., 2003. A model of macroinvertebrate trophic structure and oxygen demand in freshwater wetlands. Ecological Modelling 161:183194.

Stevenson, R.J., 1996. An introduction to algal ecology in freshwater benthic habitats. R.J. Stevenson, M.L. Bothwell and R.L. Lowe (Editors) Algal Ecology: Freshwater Benthic Ecosystems. Academic Press. New 
York, NY. pp 3-30.

Tuttle, C.L., 2005. The effects of hydrologic pulsing on aquatic metabolism in created riparian wetlands. M.S. Thesis, The Ohio State University, Columbus, OH. 179 pp.

Wang, N. and Mitsch, W.J., 2000. A detailed ecosystem model of phosphorus dynamic in created riparian wetlands. Ecological Modelling 126: 101-130.

Wu, X. and Mitsch, W.J., 1998. Spatial and temporal patterns of algae in newly constructed freshwater wetlands. Wetlands 18: 9-20.

YSI Incorporated., 2004. Environmental division. www. ysi.com. Yellow Springs, OH.

Yu, N., Culver, D.A. and Mitsch, W.J., 1997. Phytoplankton primary productivity and community metabolism at the OSU Olentangy River Wetlands. In: Mitsch, W.J.

(Editor), Olentangy River Wetland Research Park at The Ohio State University, Annual Report 1996, The Ohio State University, Columbus, OH. pp. 155-158.

Zhang, L. and Mitsch, W.J., 2005. Modelling hydrological processes in created freshwater wetlands: an integrated system approach. Environmental Modelling and Software 20: 915-946.

Zhang, L., Mitsch, W.J. and Fink, D.F., 2005. Hydrology, water quality, and restoration potential for the Upper Big Darby Creek, central Ohio. Ohio Journal of Science 105: 46-56.

Appendix A Equations, parameters and coefficients used in the simulation model

\begin{tabular}{|c|c|c|c|c|}
\hline Name & Description & Units & Initial value or equation & Source \\
\hline \multicolumn{5}{|c|}{ Hydrology submodel } \\
\hline & $\begin{array}{l}\text { inflow basin equation } \\
\text { middle basin equation } \\
\text { outflow basin equation }\end{array}$ & & $\begin{array}{l}\mathrm{dV}^{1} / \mathrm{dt}=Q_{\text {in }}+P_{1}+Q_{\text {out } 1}-E T_{1} \\
\mathrm{dV}_{2} / \mathrm{dt}=\mathrm{Q}_{\text {out } 1}+\mathrm{P}_{2}-\mathrm{Q}_{\text {out } 2}-\mathrm{ET}_{2} \\
\mathrm{dV}_{3} / \mathrm{dt}=\mathrm{Q}_{\text {out } 2}+P_{3}-Q_{\text {out } 3}-\mathrm{ET}_{3}\end{array}$ & \\
\hline V1 & inflow basin water volume & $m^{3}$ & 240 & data \\
\hline V2 & middle basin water volume & $\mathrm{m}^{3}$ & 540 & data \\
\hline V3 & outflow basin water volume & $\mathrm{m}^{3}$ & 220 & data \\
\hline Qin & river water inflow & $m^{3} d^{-1}$ & $Q_{\text {pump }}+Q_{\text {river }}$ & \\
\hline $\mathrm{Pi}$ & direct precipitation & $m^{3} d^{-1}$ & $p * A_{i}$ & \\
\hline ETi & potential evapotranspiration & $m^{3} d^{-1}$ & $e^{*} A_{i}$ & \\
\hline Qout1 & surface outflow from B1 & $m^{3} d^{-1}$ & $\mathrm{k} 1_{\mathrm{a}}{ }^{*} \mathrm{~V}_{1}$ & calibration \\
\hline Qout2 & surface outflow from B2 & $m^{3} d^{-1}$ & $\mathrm{k} 1_{\mathrm{b}}^{\mathrm{a}}{ }^{*} \mathrm{~V}_{2}$ & calibration \\
\hline Qout3 & surface outflow from B3 & $m^{3} d^{-1}$ & $\mathrm{k} 1_{\mathrm{c}}{ }^{\mathrm{b}} \mathrm{V}_{3}$ & calibration \\
\hline Qpump & pumped inflow & $m^{3} d^{-1}$ & $f($ day) & field data \\
\hline Qriver & river flood inflow & $m^{3} d^{-1}$ & f (day) & field data \\
\hline $\mathrm{p}$ & precipitation depth & $\mathrm{m}$ & f (day) & field data \\
\hline
\end{tabular}


e evapotranspiration depth from

$\begin{array}{lll} & \text { Thornthwaite eq. } & \\ \text { Vt } & \text { wetland total water volume } \\ \text { At } & \text { wetland total area } & \mathrm{m}^{3} \\ \text { W1 } & \text { wetland water level elevation m } \\ \text { A2 } & \text { inflow basin area } \\ \text { A3 } & \text { middle basin area } \\ \text { Wti } & \text { outflow basin area } \\ \text { k1a } & \text { turnover rate in basin i } \\ \text { k1b } & \text { inflow basin outflow coefficient } \\ \text { k1c } & \text { middle basin outflow coefficient }\end{array}$

$\begin{array}{ll}m & f \text { (day) } \\ m^{3} & V_{1}+V_{2}+V_{3} \\ m^{2} & f\left(V_{T}\right) \\ & f\left(V_{T}\right) \\ m^{2} & 0.24{ }^{*} A_{t} \\ m^{2} & 0.54{ }^{*} A_{t} \\ m^{2} & 0.22{ }^{*} A_{t} \\ d^{-1} & Q_{i n} / V_{i} \\ d^{-1} & 3.7 \\ d^{-1} & 1.6 \\ d^{-1} & 4.0\end{array}$

Chow, 1967

Aquatic metabolism submodel

inflow basin equation

middle basin equation

outflow basin equation

B2

B3

GPPi

$\mathrm{Ri}$

Li

Ei

S

$\mathrm{Ti}$

$f(\mathrm{Ti})$

$f(B i)$

k2

k3

k4

k5

k6

Topt

$\operatorname{Tmin}$ inflow basin standing crop

middle basin standing crop

outflow basin standing crop

gross primary production

respiration

loss due mortality

biomass export with outflow

solar radiation

water temperature in basini

temperature function

biomass self limitation

Production coefficient

Respiration coefficient

Loss coefficient

Steady-flow biomass export

coefficient

Pulse biomass export

coefficient

Optimum water temperature

for production

Minimum water temperature

for production

$$
\begin{aligned}
& \mathrm{dB}_{1} / \mathrm{dt}=\mathrm{GPP}_{1}-\mathrm{R}_{1}-\mathrm{L}_{1}-\mathrm{E}_{1} \\
& \mathrm{~dB}_{2} / \mathrm{dt}=\mathrm{E}_{1}+\mathrm{GPP}_{2}-\mathrm{R}_{2}-\mathrm{L}_{2}-\mathrm{E}_{2} \\
& \mathrm{~dB}_{3} / \mathrm{dt}=\mathrm{E}_{2}+\mathrm{P}_{3}-\mathrm{R}_{3}-\mathrm{L}_{3}-\mathrm{E}_{3}
\end{aligned}
$$

\begin{tabular}{|c|c|}
\hline kcal m-2 & 40 \\
\hline $\mathrm{kcal} \mathrm{m} \mathrm{m}^{-2}$ & 40 \\
\hline kcal m-2 & 40 \\
\hline $\mathrm{kcal} \mathrm{m}^{-2} \mathrm{~d}^{-1}$ & $k_{2}{ }^{*} S^{*} f\left(T_{i}\right) * f\left(B_{i}\right)$ \\
\hline kcal m-2 $\mathrm{d}^{-1}$ & $\mathrm{k}_{3} *\left(\mathrm{~B}_{\mathrm{i}}\right)^{2}$ \\
\hline $\mathrm{kcal} \mathrm{m}^{-2} \mathrm{~d}^{-1}$ & $\mathrm{k}_{4}{ }^{*} \mathrm{~B}_{\mathrm{i}}$ \\
\hline kcal m${ }^{-2} d^{-1}$ & $\mathrm{k}_{5}{ }^{*} \mathrm{~W}_{\mathrm{t}(\mathrm{i})}{ }^{*} \mathrm{~B}_{\mathrm{i}} \quad \mathrm{k}_{6}{ }^{*} \mathrm{~W}_{\mathrm{t}(\mathrm{i})}{ }^{*} \mathrm{~B}_{\mathrm{i}}$ \\
\hline kcal m $\mathrm{m}^{-2} \mathrm{~d}^{-1}$ & $f($ day) \\
\hline${ }^{\circ} \mathrm{C}$ & f (day) \\
\hline N/A & $e^{-2.3 /(T 1-\text { Topt)/(Topt - Tmin)1 }}$ \\
\hline \multirow[t]{2}{*}{$\mathrm{N} / \mathrm{A}$} & $\mathrm{B}_{\mathrm{i}} /\left(50+\mathrm{B}_{\mathrm{i}}\right)$ \\
\hline & 0.006 \\
\hline $\mathrm{m}^{-2} \mathrm{kcal}^{-1}$ & 0.001 \\
\hline$d^{-1}$ & 0.01 \\
\hline$d^{-1}$ & 0.01 \\
\hline$d-1$ & 0.2 \\
\hline${ }^{\circ} \mathrm{C}$ & 28 \\
\hline${ }^{\circ} \mathrm{C}$ & 6 \\
\hline
\end{tabular}

calibration

calibration

calibration

calibration

calibration

calibration

estimation

field data

field data

Jorgensen,

1978

Spieles and

Mitsch, 2003

field data

calibration

calibration

calibration

calibration

Kayombo et al., 2002

Kayombo et al., 2002

\section{Dissolved Oxygen Submodel}

inflow basin equation

middle basin equation

outflow basin equation

DO1
DO2
DO3
DOin inflow basin dissolved oxygen $\mathrm{g}$

middle basin dissolved oxygen

outflow basin dissolved oxygen

DO in with inflow water
$\mathrm{dDO}_{1} / \mathrm{dt}=\mathrm{DO}_{\text {in }}+\mathrm{DO}_{\mathrm{gpp}}$

$-\mathrm{DO}_{\mathrm{r}}-\mathrm{DO}_{\text {out1 }} \pm \mathrm{DO}_{\mathrm{d}}$

$\mathrm{dDO}_{2} / \mathrm{dt}=\mathrm{DO}_{\text {out1 }}+\mathrm{DO}_{\mathrm{gpp}}$

$-\mathrm{DO}_{\mathrm{r}}-\mathrm{DO}_{\text {out2 }} \pm \mathrm{DO}_{\mathrm{d}}$

$\mathrm{dDO}_{3} / \mathrm{dt}=\mathrm{DO}_{\text {out2 }}+\mathrm{DO}_{\mathrm{gpp}}$

$-\mathrm{DO}_{\mathrm{r}}-\mathrm{DO}_{\text {out3 }} \pm \mathrm{DO}_{\mathrm{d}}$

1000

2000

1000

[DO ${ }^{*} Q_{\text {in }}$ calibration calibration calibration field data 
100 The Olentangy River Wetland Research Park 2005

\begin{tabular}{|c|c|c|c|c|}
\hline DOP & DO production & $\mathrm{g} \mathrm{d}^{-1}$ & $\operatorname{GPP}_{i}{ }^{*} a_{1}{ }^{*} A_{i}$ & \\
\hline DOR & DO respiration & $\mathrm{g} \mathrm{d}^{-1}$ & $R_{i}{ }^{*} a_{1}{ }^{*} A_{i}$ & \\
\hline DOout & export with surface outflow & $\mathrm{g} \mathrm{d}^{-1}$ & {$[\mathrm{DO}]_{\mathrm{i}}{ }^{*} \mathrm{Q}_{\mathrm{out}(1)}$} & \\
\hline DOd & $\begin{array}{l}\text { DO diffusion between the } \\
\text { water and atmosphere }\end{array}$ & $\mathrm{g} \mathrm{d}^{-1}$ & & \\
\hline DOsat & $\begin{array}{l}\text { Dissolved oxygen saturation } \\
\text { at } \mathrm{Ti}\end{array}$ & $\mathrm{g} \mathrm{m}^{-3}$ & & $\begin{array}{l}\text { Clesceri et al, } \\
1999\end{array}$ \\
\hline a1 & conversion factor & kcal: $\mathrm{gO}_{2}$ & 3.7 & $\begin{array}{l}\text { Mitsch and } \\
\text { Gosselink, } 2000\end{array}$ \\
\hline k7 & DO diffusion coefficient & $\mathrm{g} \mathrm{m}^{-2} \mathrm{~d}^{-1}$ & 2.0 & Calibration \\
\hline
\end{tabular}

